\title{
Gene therapy technology applied to disorders of glucose metabolism: promise, achievements, and prospects
}

\author{
Nick Giannoukakis and Massimo Trucco
}

BioTechniques 35:122-145 (July 2003)

\begin{abstract}
Gene transfer technology has spawned an entire realm of clinical investigation, collectively referred to as "gene therapy." The feasibility and achievements of gene therapy to prevent and treat glucose homeostasis disorders, with particular emphasis on diabetes mellitus, are evaluated in this review. While a considerable amount of effort has yielded gene delivery vectors based on adenoviral, retroviral, and herpes simplex virus DNA, the number of successful clinical applications has not been as impressive. Despite the number of successes in vitro and in animal models, preliminary safety trials in humans have not yet been attempted. The current state of this science, outlined here, underlines the necessity of marrying gene transfer technology with cell therapy. The ex vivo transfer of gene combinations into a variety of cell types will likely prove more therapeutically feasible than direct in vivo vector transfer. Current efforts aimed at assessing the future of gene therapy for diabetes must, at the very least, take into account the importance of moving successful methods into human safety trials.
\end{abstract}

\section{INTRODUCTION}

Diabetes mellitus refers to a multitype disorder of glucose homeostasis defined by the loss of insulin production and/or the insensitivity of peripheral tissues to the effects of insulin. Generally, the disorder falls into two categories: type 1 and type $2(1-4)$. The loss of insulin due to the autoimmune destruction of the $\beta$ cells defines type 1 diabetes mellitus. Impaired glucose sensitivity and/or insulin production by pancreatic $\beta$ cells in the presence or absence of poor sensitivity to the effects of insulin in the periphery define type 2 diabetes, which is commonly diagnosed in adults. Often, obesity is a significant risk factor for type 2 diabetes (5-7). Today, the conventional treatment for type 1 diabetes remains insulin replacement. Pharmacologic agents acting at the level of the $\beta$ cell to improve glucose sensitivity and insulin production, along with drugs that can sensitize the peripheral tissues to the effects of insulin, are the forefront of the effort aimed at restoring good glucose control in type 2 diabetics. In addition, several bioactive peptides have also been discovered that have potent effects on insulin production and are currently in various stages of clinical development (8-10). However, insulin replacement and the various pharmacologic agents cannot be considered "cures." Despite the significant improvements in glycemic control, these strategies are unable to achieve permanent, normal, physiological glucose control. The consequences include diabetes complication-associated morbidity and mortality (11). In fact, nonphysiologic glucose control is a predominant risk factor for cardiovascular, renal, and ophthalmic diseases. Where traditional pharmacological therapies fall short, bioengineering strategies offer an alternative.

Gene transfer technology is the cornerstone of gene therapy, widely cited as an alternative approach to, or as a complement of, traditional pharmacotherapy in several human disorders.
Indeed, a number of studies in animals have demonstrated the potential of this technology in type 1 diabetes $(12,13)$. While advances in metabolic engineering of cells have not kept pace with those in the field of immune regulation; nonetheless, several approaches for engineering surrogate $\beta$ cells are equally promising. In this review, we outline the technologies that have been used in gene therapy strategies for disorders of glucose homeostasis, with a special emphasis on diabetes mellitus. We illustrate the successful applications of gene transfer technology and current limitations. We conclude with some proposals that could serve as the basis of further investigation.

\section{DISORDERS OF GLUCOSE HOMEOSTASIS}

While several human disorders have impairments in glucose homeostasis (hyperglycemia/hypoglycemia) as their symptoms; often, this is a consequence 
of the disorder and transient. Primary chronic hyperglycemia is synonymous with type 1 and type 2 diabetes mellitus, and type 2 diabetes is closely associated with obesity. To uncover targets of intervention, it is important to understand the molecular mechanisms of the etiology and progression of these disorders.

Type 1 diabetes is an autoimmune disorder whose onset occurs at a very early age and, in most patients, results in pancreatic $\beta$ cell impairment or destruction by the time of diagnosis, which requires insulin replacement. It is a $\mathrm{T}$ cell-driven disease that relies on the presence of specific HLA alleles that are often found clustered in families $(1,2,14,15)$. Despite the confirmation that the disorder has a genetic basis, the significant concordance between twins and the mapping of susceptibility loci, type 1 diabetes is thought to involve an environmental trigger $(2,15)$. The $\mathrm{T}$ cell specificity for pancreatic $\beta$ cell antigens exposes an underlying defect of central tolerance mechanisms and, very likely, dysfunctional peripheral immunoregulation.

In contrast, type 2 diabetes is consequence of several, often overlapping, physiological and cellular defects, with only sporadic evidence of an autoimmune component (16). Type 2 diabetes mellitus is associated with insulin deficiency and insulin resistance. It is still unclear where the primary defect lies and which of the two is a secondary response, although many studies support insulin deficiency as secondary to peripheral resistance $(3,17)$. Genetic and environmental factors contribute to the etiology of type 2 diabetes mellitus, with the concordance rate in identical twins at $90 \%$ with variable prevalence among different populations. More than 50 genes have been identified that are involved in glucose homeostasis, which suggests that the cause of type 2 diabetes is heterogeneous and will likely involve defects in many pathways that play a role in insulin expression, secretion, and sensitivity and that even this alone will define only a subset of cases $(3,17)$.

Obesity is probably the most important environmental risk factor for type 2 diabetes. Obesity induces insulin resistance in both humans and animal models of type 2 diabetes $(5,18,19)$. Several genetic defects have been discovered that implicate the leptin pathway as a key regulator of satiety and obesity $(18,19)$. Leptin-deficient and leptin receptor-deficient mice and rats are obese and exhibit many characteristics of type 2 diabetes to varying degrees. The importance of leptin in human obesity, insulin resistance, and type 2 diabetes, however, remains to be determined, although there is no current evidence to support leptin defects as causal of human obesity or diabetes $(18,19)$.

A role for free fatty acids in insulin resistance and type 2 diabetes etiopathogenesis has been proposed by a number of studies, following the observation that chronic elevation of serumfree fatty acid concentrations in obese or diabetic individuals is associated with decreased glucose uptake into peripheral tissues (20-22).

\section{GENE THERAPY TECHNOLOGY}

It is evident from the physiology that some tissues and cell types are targetable by, and exploitable for, gene engineering to achieve one or more desired therapeutic benefits. For type 1 diabetes, the cells of the immune system can be targets of molecular vehicles that carry genes or proteins able to induce immunosuppression in a spatially confined manner and with restricted tissue distribution. In parallel, transplantation of insulin-producing tissues can be engineered to resist rejection with no need for the chronic administration of toxic immunosuppressive drugs. Additionally, understanding the process of $\mathrm{T}$ cell maturation can assist in designing gene engineering strategies that can prevent the onset of autoimmunity.

While it may not be readily apparent why gene therapy can or should be applied to type 2 diabetes, most of the pharmacologic interventions used to treat insulin resistance (a preface to overt diabetes) eventually fail, which suggests that a targeted approach may be more able to prolong the time to onset of insulin resistance or prevent it altogether. While "insulin resistance" genes have yet to be identified, type 2 diabetes has been associated in rodents and humans with specific mutations/ polymorphisms of glucoregulatory, glucose-sensing genes, or is preceded by obesity and insulin resistance that may or may not be underlined by genetic susceptibility $(3,23)$, which suggests that gene therapeutic strategies aimed at type 2 diabetes should be based on a knowledge of the biochemistry of glucose-sensing, insulin sensitivity, and fuel metabolism. Targeting one or more of these pathways may achieve the identical results as current pharmacologic therapy, with no risk of the toxicity inherent in some of the more aggressive and potent agents currently in clinical use.

To deliver genes into cells and tissues, it is necessary to identify the "engineerability" of a cell; whether it is a dividing cell, differentiating cell, cell with limited lifespan, or cell with high metabolic activity. These factors will determine the choice of vector system that will facilitate the conferring of an exogenously demanded activity to a cell. Currently, vector systems fall into two broad categories, each with their advantages and limitations. We will describe these in the context of gene therapy for diabetes mellitus. Table 1 illustrates the general properties of the two vector categories, viral and nonviral.

\section{Viral Vectors}

The generation of viral gene delivery vectors requires two major components: vectors encoding a complete, or components of, viral genome sequence that is engineered in such a manner that no replication-competent particles can be generated. Additionally, the gene or genes that achieve the desired therapeutic or prophylactic objective are supplied as part of the viral sequence or separately in another DNA sequence. The second component is a cell line that can efficiently produce recombinant virions that do not have the capacity to replicate once they infect a host. Several strategies are currently employed to generate replication-defective adenoviral vectors (Figure 1) (24-34), and some are commercially available. Table 1 outlines the reasons adenoviruses are versatile. Their most important feature is the ability to generate these vectors in high titers and to infect a broad range of cell types $(24,25)$. It is therefore not 
surprising that the greatest number of gene therapy approaches in vitro and in vivo have been carried out with adenoviruses. The major limitation of these vectors is their immunogenicity, which is very likely dependent on the presence of expressed sequences in the vector backbone $(24,25)$. If the aim is to generate a state of localized immunosuppression, then such a feature is intuitively counterproductive. Several strategies have succeeded in generating "gutless" adenoviral vectors, but to date, it has been challenging to grow these vectors to high titer without the presence of contaminating helper virus $(24,25)$. Adeno-associated vectors offer advantages over adenoviruses, and recent data suggest their potential benefits (35-40). What is clear is that the utility and versatility of novel viral vectors are ultimately compared to that of adenoviruses; generally, adenoviruses are the benchmark.

Retroviral vectors were among the earliest choice vectors in gene therapy models. They easily infect replicating cells and integrate into the host genome. Actively replicating immune cells, especially $\mathrm{T}$ cells, were among the first cell types to be transduced by retroviruses. Their generation is straightforward, and several cell lines and processes are currently commercially available. Primarily based upon the Moloney murine leukemia virus (MMLV) genome, retroviral vectors have evolved into embodiments of avian, bovine, feline, equine, and human retroviruses (27-30,32,34).

The properties of human immunodeficiency virus (HIV)-1 were exploited to develop the first vectors of the Lentiviridae family. Lentiviral vectors

Figure 1. Construction of viral vectors. (A) Adenoviral vectors. Cell lines expressing adenoviral helper and packaging functions are transfected with transfer plasmids encoding the transgene of interest. Recombination of homologouos sequences occurs within the cells. Newer developments take advantage of recombination within appropriate bacterial hosts, minimizing nonrecombinant vector production in cells. (B) Retroviral vectors. Transfer plasmids encoding transgenes are transiently transfected into packaging cell lines. (C) Herpes viral vectors. To construct a vector that is ICP4- and ICP22- (deletions in crucial genes that are necessary for replication competency), ICP4viral DNA is transfected into a producer cell line with a transfer plasmid in which the transgene cassette is cloned inside the deleted ICP22 locus.
A
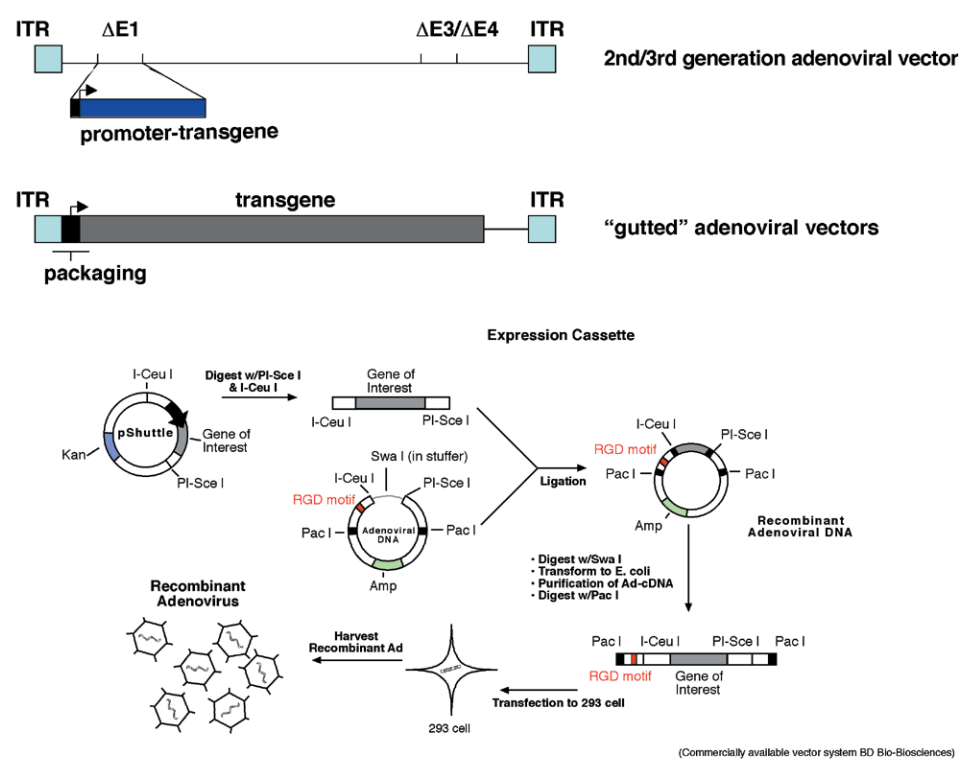

B

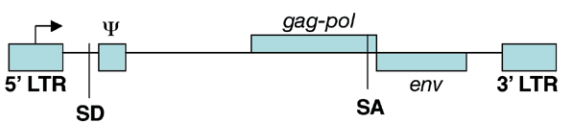

Retroviral backbone

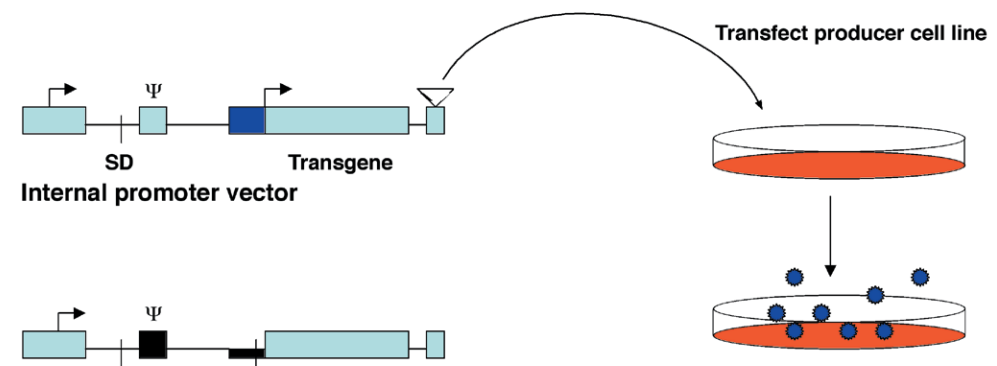

Harvest recombinant retroviral vectors

LTR-driven vector

C

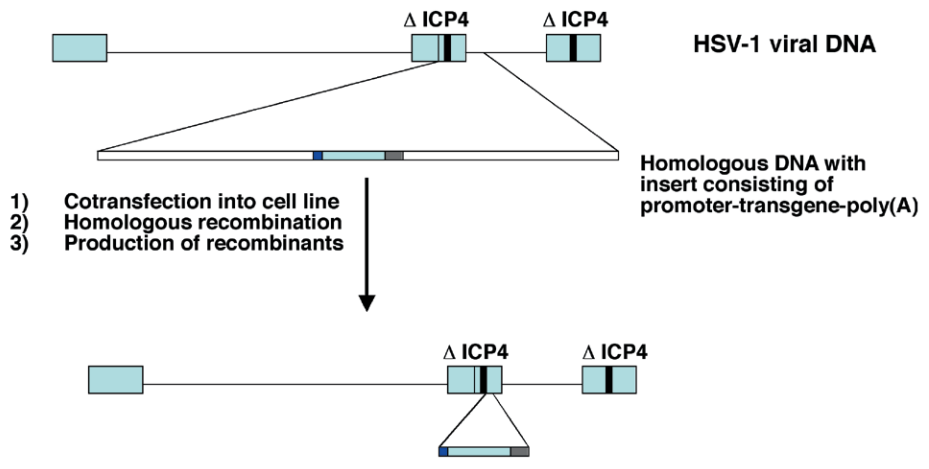


offer low to no immunogenecity, but their cell range is limited, and the titers achievable on a packaging cell basis are significantly lower compared to adenoviruses. In the diabetes context, they can infect cells that are poorly transducible by adenoviral vectors and offer the advantage of stable genomic integration. This is a desired feature in approaches aimed at engineering cells that do not divide, differentiate, and are long-lived (27-30,32,34).

A limitation of all the aforementioned vectors is the transgene size that can be accommodated inside the vector backbone. Where strategies envisage multicistronic transgenes and/or promoters of complex (and long length) structure, solutions are provided by the herpes simplex viruses $(26,28,41)$. While earlier generations of these vectors were toxic to transduced cells, current embodiments do not promote significant levels of cell toxicity in vitro or in vivo (42-46). A disadvantage is the cumbersome process required to generate significant titers, but ongoing efforts at large-scale vector production promise to overcome this limitation (42-46).

\section{Nonviral Vectors}

While viral vectors are versatile for almost all gene therapy applications, the immunogenicity, toxicity, potential for replication competency, the potential of wild-type helper virus carryover during production, and the sheer logistics required to maintain good manufacturing procedures/good laboratory procedures facilities for clinical-grade vectors are considered to offer more challenges than solutions. Nonviral vectors offer an inexpensive alternative. Traditionally, the transfer of naked DNA plasmids was synonymous with nonviral vectors; however, several recent developments have welcomed new types of gene transfer vehicles that contain no viral elements.

Naked recombinant DNA plasmid generation is rapidly scalable with considerably lower cost compared to viral vectors. Newer generation plasmid vectors have been designed to either stimulate immune responses or to have a low immunogenic profile $(33,47-51)$. Additionally, multicistronic vectors are easily achievable compared to chal- lenges to generate the same in viral vectors. Nonetheless, naked DNA cannot attain stable transgene persistence in transduced cells, and high concentrations are often required in multiple dosings (Table 1).

Newer approaches have succeeded in exploiting amino acid sequences that act as a cell entry facilitator of intact proteins. These peptide transduction domains (PTDs) are derived from viral nuclear import proteins and, unlike viral and plasmid DNA vectors that require gene transcription and translation for transgene expression, the PTDs are fused to the protein of interest. PTDfused proteins can be readily generated in high yield with relatively minimal logistical requirements $(52-56)$. The nature of the PTD domain can be modified to improve cell-type targeting. Their limitation, however, lies in their relatively short half life, as they are subject to proteasome-dependent proteolyis. Whatever the choice of vector, all have been tested in the context of gene therapy for diabetes, with varying outcomes.

\section{THE PROMISE, ACHIEVE- MENTS, AND PROSPECTS}

The most obvious form of physiological glucose regulation in diabetic individuals has been insulin replacement. It is now evident that pharmacologic insulin replacement, although able to achieve tight glucoregulation, cannot prevent the complications. The alternative that many have aspired to has been to facilitate islet transplantation or to engineer surrogate $\beta$ cells. While the recent successes achieved by glucocorticoid-free immunosuppression have propelled islet transplantation closer to routine clinical consideration, pharmacologic immunosuppression is in fact detrimental to the long-term survival of islet transplants, necessitating a local form of immunosuppression that is adequate to control the rejection of the transplant without affecting the host immune response at a systemic level.

For diabetes, the choice of approach depends on the very nature of the underlying defect. In type 1, the objective is to educate the host immune system to eliminate autoreactive $\mathrm{T}$ cells before the clinical onset of the disease or to re- 
Table 1. General Characteristics of Gene Delivery Vehicles

\begin{tabular}{|c|c|c|}
\hline Vector type & Advantages & Disadvantages \\
\hline \multicolumn{3}{|l|}{ VIRAL } \\
\hline Adenovirus & $\begin{array}{l}\text { Choice vector for pilot proof-of-principle } \\
\text { experiments; high titers easily obtained; } \\
\text { almost all cells and tissues are transducible; } \\
\text { and cell retargeting is possible. }\end{array}$ & Immunogenic in vivo; nonstable transduction. \\
\hline $\begin{array}{l}\text { Adeno-associated virus } \\
\text { (AAV) }\end{array}$ & $\begin{array}{l}\text { Site-specific, stable integration achievable; } \\
\text { almost absent immunogenicity; and many } \\
\text { cell types transducible. }\end{array}$ & Time for transgene expression can be days. \\
\hline $\begin{array}{l}\text { Moloney murine leukemia } \\
\text { virus (MMLV)-based } \\
\text { retrovirus }\end{array}$ & $\begin{array}{l}\text { Stably integrating vector in rapidly dividing } \\
\text { cells; cell-type retargeting possible; and good } \\
\text { titers are obtainable. }\end{array}$ & $\begin{array}{l}\text { Subject to chromosomal position-effect sensitivity } \\
\text { of, as well as methylation and cytokine effects on, } \\
\text { gene expression. }\end{array}$ \\
\hline Lentivirus & $\begin{array}{l}\text { Nonimmunogenic, stably integrating; choice } \\
\text { vector for nondividing, noncycling cells; } \\
\text { good titers obtainable; data support absence } \\
\text { of replication-competent-recombinant vector } \\
\text { particles in stocks. }\end{array}$ & $\begin{array}{l}\text { Clinical safety concerns with human } \\
\text { immunodeficiency virus (HIV)-1-based vectors. }\end{array}$ \\
\hline $\begin{array}{l}\text { Herpes simplex type- } 1 \\
\text { virus }\end{array}$ & $\begin{array}{l}\text { Large genome available for multiple large } \\
\text { size cistrons; good persistence in many cell } \\
\text { types; and cell-type retargeting possible. }\end{array}$ & Inherent toxicity. \\
\hline \multicolumn{3}{|l|}{ NONVIRAL } \\
\hline Plasmid DNA & $\begin{array}{l}\text { Easy to engineer, grow, and purify; and } \\
\text { multicistronic variants are easy to engineer. }\end{array}$ & $\begin{array}{l}\text { Poor persistence, nonspecific cell targeting, and } \\
\text { poor dissue diffusion. }\end{array}$ \\
\hline Cationic liposome & $\begin{array}{l}\text { Easy to manipulate to deliver plasmid DNA } \\
\text { to almost all cells and tissue. } \\
\text { Nonimmunogenic; cell-type nonspecific, and } \\
\text { cell-type retargeting possible. }\end{array}$ & Poor control of diffusion kinetics. \\
\hline Peptide fusion domains & $\begin{array}{l}\text { Many cell-types transducible; high-level } \\
\text { protein/peptide import; intact proteins/ } \\
\text { peptides delivered; not subject to gene } \\
\text { regulation; targeting of specific proteins } \\
\text { possible; high-level peptide production easily } \\
\text { achievable; and no reported immunogenicity. }\end{array}$ & $\begin{array}{l}\text { Short half life; subject to proteolytic degradation; } \\
\text { and large amounts require some time to } \\
\text { generate. }\end{array}$ \\
\hline
\end{tabular}

place the lost $\beta$ cells with either intact islets or surrogate $\beta$ cells. In type 2 diabetes, the objective is to initially restore metabolic control by regulating fuel metabolism, insulin sensitivity and production, and glucose uptake.

In general, there are two strategies that can be employed to generate a cell or gene drug: ex vivo engineering or in vivo delivery. In the ex vivo approach, a cell that will be used as a transgene factory is isolated from the host and manipulated in the laboratory. This may or may not involve cell expansion.
Most gene therapy strategies employ this approach. The in vivo interventions are more difficult because the targeting of the gene delivery vehicle becomes an issue and is currently difficult to achieve, unless the targeted site is where the correction is being made and is easily accessible.

Many of the approaches for type 1 diabetes involve gene transfer to cells ex vivo. Consequently, one must take into the account the nature of the cell to employ an appropriate delivery vector. The primary target cell type has been the $\beta$ cell in the form of intact islets for subsequent transplantation and immune cells of different types, most commonly the antigen-presenting cells or T lymphocytes. The in vivo approaches could involve targeting to the pancreas to organs and sites involved in immune stimulation, such as the thymus and the peripheral lymphoid organs.

To introduce a therapeutic transgene to $\beta$ cells ex vivo, the delivery vehicle must be able to transduce these almost nondividing cells and to remain in the cell for its entire lifetime. The most 


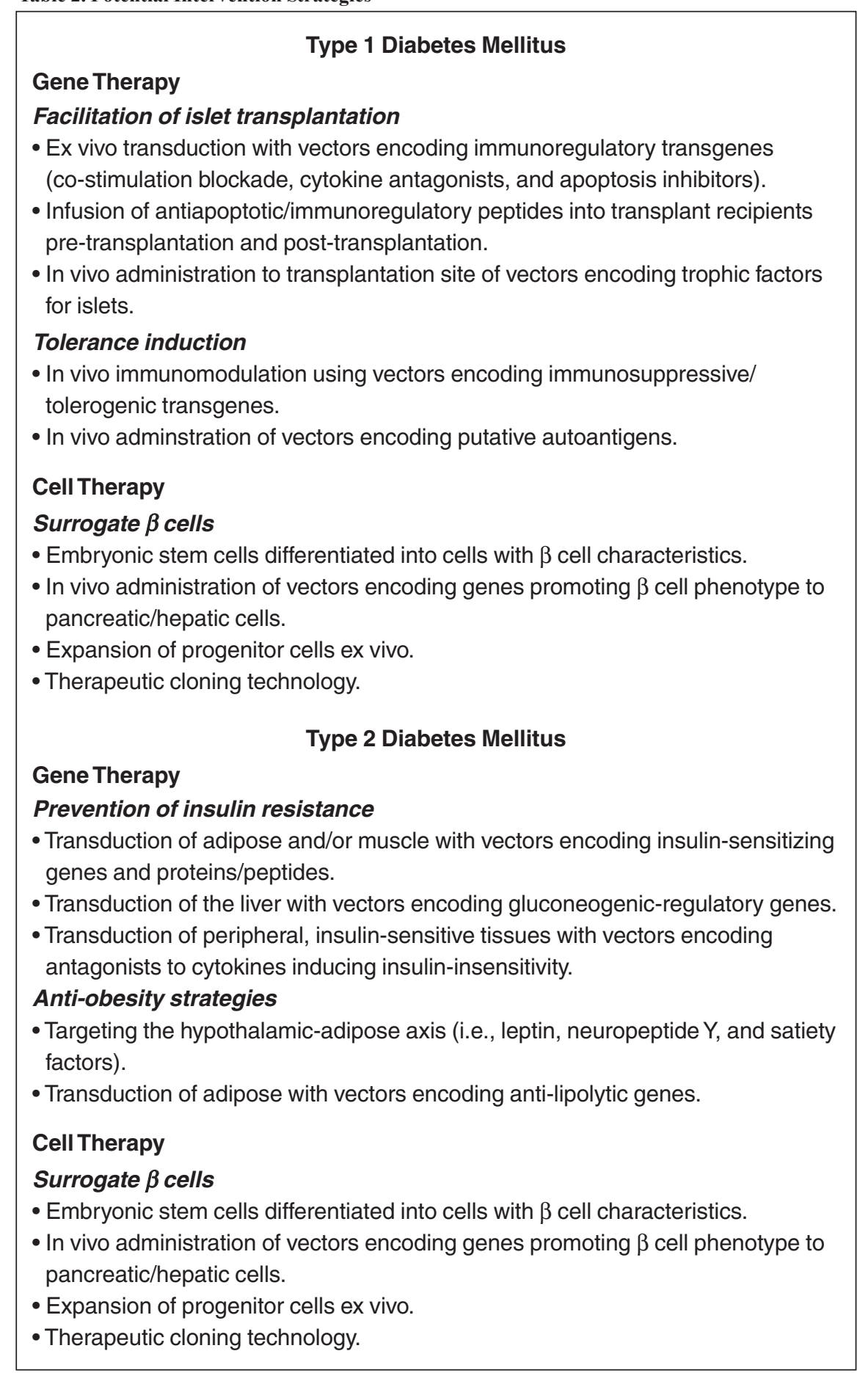

versatile delivery vehicles are replication-deficient viral vectors, and Table 1 lists their advantages and disadvantages. In subsequent sections, their utility in various experimental models of type 1 diabetes gene therapy will be discussed. For peripherally derived antigen-presenting cells, the require- ment for long-term expression may not be as stringent as for the $\beta$ cells, primarily because the source of these cells (i.e., peripheral blood) is easily accessible. In this instance, novel approaches in addition to viral gene delivery can be employed. An example is the newly discovered peptide delivery vectors 
Table 3. Current Approaches for Type 1 Diabetes Gene and Cell Therapy

\begin{tabular}{|c|c|c|}
\hline $\begin{array}{l}\text { Gene Vectors that Transduce Islets } \\
\text { (with References) }\end{array}$ & $\begin{array}{l}\text { Genes that Promote Islet Allograft/ } \\
\text { Xenograft Survival In Vitro and In } \\
\text { Vivo and/or } \beta \text { Cell Survival in Culture }\end{array}$ & $\begin{array}{l}\text { Other Gene/Cell Therapy } \\
\text { Approaches to Prevent/Abrogate } \\
\text { Autoimmunity and/or Promote Islet } \\
\text { Allograft/Xenograft Survival }\end{array}$ \\
\hline Plasmid DNA $(173,193-195)$ & Anti-apoptotic genes & $\begin{array}{l}\text { Bone marrow transplantation/ } \\
\text { chimerism induction }\end{array}$ \\
\hline Adenovirus (196-209) & bcl-2 (214,216,224-226) & $(178,243-253)$ \\
\hline AAV (210-219) & bcl- $x_{L}(52,227)$ & \\
\hline MMLV-based retrovirus (220) & heme oxygenase-1 (228-230) & Antigen-presenting cell (APC) \\
\hline Lentivirus (221-223) & dominant negative protein kinase $\mathrm{C}$ & transfer \\
\hline Herpes simplex virus $(224,225)$ & delta (231) & class I MHC (163) \\
\hline Cationic liposomes $(194,195,204)$ & dominant negative MyD88 (232) & autologous dendritic cell (DC) \\
\hline \multirow[t]{19}{*}{ Peptide fusion domains $(52,53,56)$} & IGF-I (233) & transfer $(254)$ \\
\hline & Ік $\beta \alpha$ super-repressor (209) & \\
\hline & Hsp70 (234) & Co-stimulation blockade \\
\hline & A20 (205) & soluble ICAM-1-lg (255) \\
\hline & PEA-15 (52) & CTLA-4lg (256-260) \\
\hline & catalase $(235,236)$ & OX40lg (259) \\
\hline & $\begin{array}{l}\text { manganese superoxide dismutase } \\
(237,238)\end{array}$ & $\begin{array}{l}\text { Cytokines } \\
\text { IL-10 (239,261-263) }\end{array}$ \\
\hline & Cytokines & IL-4 $(262,264)$ \\
\hline & IL-4 (221) (although one report & soluble IFN $\gamma$ receptor $(187,265)$ \\
\hline & demonstrated no protection) (196) & TGF $\beta(266)$ \\
\hline & IL-1 receptor antagonist protein (208) & \\
\hline & IL-12p40 (197) & Autoantigen transfer \\
\hline & viral IL-10 $(198,239)$ & glutamic acid decarboxylase (GAD) \\
\hline & $\begin{array}{l}\text { IL-10 }(240) \text { (one report did not show } \\
\text { protection) (196) }\end{array}$ & $(267)$ \\
\hline & $\begin{array}{l}\text { TGF } \beta \text { (240) (one report showed } \\
\text { negative results) (241) }\end{array}$ & $\begin{array}{l}\text { Others } \\
\text { adenovirus E3 proteins (268)F } \\
\text { orally administered putative }\end{array}$ \\
\hline & Immunoregulatory genes & autoantigens (insulin and GAD) \\
\hline & Indoleamine 2,3-dioxygenase (215) & (269-271) \\
\hline & CTLA-4lg (173) & CD152 (272) \\
\hline & $\begin{array}{l}\text { Fas ligand (199) (although in several } \\
\text { reports, the Fas ligand was not } \\
\text { protective) (242) } \\
\text { adenoviral E3 genes (200) }\end{array}$ & \\
\hline
\end{tabular}

that can introduce proteins in their native forms across the cell and the nuclear membrane $(53,57,58)$. These peptide-protein conjugates can be generated quite readily and have been shown to transduce many cell types in culture, including islet $\beta$ cells (56).

However, in vivo gene delivery is more challenging and will require appropriate targeting. The direct injection of adenoviral vectors into the pancreas of rats has been attempted, as has plas- mid DNA and adenoviral gene delivery to the thymus (59). Whether these approaches can become more efficient or clinically useful remains to be explored.

Type 2 diabetes, on the other hand, may be better suited for in vivo gene delivery at either the sites of metabolic defects or at sites where the biochemistry can be manipulated to restore normal glucose levels. For example, because insulin action on glucose metabolism is mainly on skeletal mus- cle and adipocytes, one could target large muscle groups or sites of fat deposit with viral vectors (Table 1 ) to improve insulin sensitivity or to substitute skeletal muscle as a site of increased glucose uptake where other sites are defective. This approach can entail the use of direct injection of viral vectors or, as recently identified $(60,61)$, injection of skeletal muscle stem cells that, once obtained from an autologous host, could be modified ex vivo with viral 
gene vectors, expanded, and transplanted back into a large muscle group. However, pancreatic defects will probably require either direct injections into the pancreatic vasculature or islet/surrogate $\beta$ cell transplantation. Whatever the defect, type 2 diabetes gene therapeutics will most likely be patient-specific because the defects among the patients are not expected to be identical.

Table 2 lists the general strategies aimed at therapeutic or prophylactic end points. Several vectors and transgenes, used to confer immune privilege and to bolster intrinsic defenses of the $\beta$ cell, are listed in Table 3. Note that all of the studies we will describe have been performed in human or rodent islet $/ \beta$ cell cultures or rodents in vivo. The results have been mixed. To date, there is no single transgene that has conferred significant long-term protection to transplanted islets in allogeneic diabetic rodent recipients. Moreover, although monogenic gene transfer to human or rodent islets has thus far been unable to prevent autoimmune rejection, as evidenced in rodent models of autoimmune diabetes, it is possible that multigenic gene transfer, which combines the properties of two or more transgenes in protecting islets at multiple levels or uses two or more vectors each encoding different genes, may succeed. Additionally, not all "immunoregulatory" genes have been tested. In the absence of these data, it would be unwise to view the transplantation of gene-engineered islets expressing multiple immunoregulatory genes as unfeasible or without potential. These studies must be carried out before reaching any general conclusion.

In parallel with the transplantation of gene-engineered islets, several attempts have been made to generate surrogate $\beta$ cells from rodent or human progenitors. The most popular approach has been to convert hepatocytes or hepatocyte cell lines into glucosesensitive insulin-producing cells for the purpose of transplantation. Direct in vivo administration of such vectors has also been attempted. Adenovirus has been the choice vector in these strategies, and several transgenes have been tested in the context of putative glucose-sensitive promoter elements.
Hepatocytes are particularly attractive because they can easily engraft in the liver, and because they possess glucose-sensing molecules identical to the pancreas [e.g., GLUT2 and glucokinase (GK)]. Furthermore, one can exploit several hepatocyte gene promoters that are sensitive to glucose to engineer insulin transgenes to be glucose concentration-sensitive. The disadvantages of hepatocytes, however, lie in their inability to secrete the insulin in a glucose-responsive fashion and their lack of $\mathrm{PC} 2$ and $\mathrm{PC} 3$ pro-convertases and carboxypeptidase $\mathrm{H}$, required to process proinsulin to its mature form $(62,63)$. Despite these limitations, Groskreutz et al. (64) were able to engineer human proinsulin to contain furin cleavage sites at the natural sites of proinsulin processing. Furin is a ubiquitous protease that is also found in hepatocytes. This form of proinsulin was properly processed into active and mature insulin in transfected human kidney cells and rat primary myoblasts and possessed insulin receptor binding and activation activity similar to native insulin. Recent efforts have confirmed that hepatocytes are equally efficient at producing and processing this furin site-modified proinsulin into a mature, bioactive form (65). The need to express proinsulin in a glucose-dependent manner compelled Mitanchez et al. (66) to engineer transgenic mice expressing the human proinsulin cDNA or the furin cleavage site variant under the transcriptional control of the glucose-responsive liver isoform pyruvate kinase (LPK) promoter-enhancer elements. Insulin was expressed in the liver, kidney, and gut of these transgenic mice, and immunoreactive C-peptide was readily detectable in serum. Moreover, its levels were sensitive to levels of carbohydrates (66). More studies on this system using adenoviral gene transfer to the liver have recently been reported by Thule et al. $(67,68)$, who have shown its potential in a streptozoticin-treated rat model. Very recently, Lee and colleagues (69) were able to achieve the complete restoration of normoglycemia in diabetic rats following recombinant adeno-associated virus (rAAV) gene transfer of a single-chain insulin transgene under the control of the LPK pro- 
moter. Additionally, they obtained the same success in non-obese diabetic (NOD) mice. While these data are very compelling, the kinetics of changes in serum glucose concentration are not in harmony with the known kinetics of transcriptional activation of the LPK promoter. Furthermore, insulin secretion by hepatocytes is not glucose-regulated. In a related approach, Chen et al. $(70,71)$ demonstrated in hepatoma cell culture that adenoviral gene transfer of insulin driven by the glucose-6phosphatase promoter resulted in glucose-responsive, self-limiting insulin production, although these data are not clear on whether this approach can be successful in vivo.

Despite these promising approaches, much more work is needed to make hepatocytes into fully surrogate $\beta$ cells. First, their response to glucose is not as rapid as that found in $\beta$ cells. Second, the liver-specific glucose-sensitive promoters have elements that respond to hormonal and metabolic signals, which can impede, attenuate, or abrogate the desired objective of tight glucose regulation. For example, instances of hyperglucagonemia, which are to be expected in the absence of functional endogenous $\beta$ cells in diabetics, will most likely attenuate or repress the LPK promoter and other promoters such as GK (72-74). Third, glucose-dependent transactivation of the LPK promoter requires the GK-dependent phosphorylation of glucose, an activity that is insulin-dependent (66). Other promoters have been suggested, such as phosphoenolcarboxykinase (PEPCK), but this promoter is activated by glucagon and inhibited by insulin, which may not result in the desired kinetics of physiological glucoregulation $(75,76)$. It is possible that a combination of promoter elements from different glucose-responsive hepatic genes may be required to create an optimal synthetic promoter to drive hepatic insulin expression in a true glucose-sensitive fashion.

In addition to hepatocytes, one of the earliest approaches involved the genetic modification of an adrenocorticotrophic hormone (ACTH)-secreting neuroendocrine cell line (AtT20) to secrete human proinsulin where proinsulin expression was under the control of a viral promoter (77). The advantage of these cells was they shared some features with $\beta$ cells; namely, their possession of secretory granules and the expression of the PC2 and PC3 proconvertases and carboxypeptidase $\mathrm{H}$, which cleave proinsulin to its mature form (78). Further manipulations of the cell line resulted in derivatives that expressed GK and GLUT2, the high Km glucose transporter of $\beta$ cells. These cells were able to secrete insulin in a glucose concentration-dependent manner and responded to insulin secretagogues potentiated by glucose, which are features that are inherent in $\beta$ cells (79). Despite this, the basal insulin release by these cells is higher than that of $\beta$ cells. Another concern in the use of these cell lines is the effect of GLUT2, which is permissive for the secretion of ACTH and possibly other pro-opiomelanocortin-derived hormones in a glucose-dependent manner (66), potentially leading to iatrogenic Cushing's syndrome. Furthermore, the cytomegalovirus promoter may become inactive in vivo (80).

More recently, tissue-specific promoters have been exploited to engineer cells to express insulin in cells that are not targets of autoimmune destruction. Lipes et al. $(81,82)$ have expressed insulin in the anterior pituitary of NOD mice under the control of the pro-opiomelanocortin promoter. Insulin was expressed, stored in secretory granules, and exhibited regulated secretion. Moreover, the transplantation of transgenic anterior pituitary tissue to NOD mice was able to partially restore normoglycemia with no signs of immune rejection $(81,82)$. However, it was unclear if insulin secretion was glucose concentration-dependent in these cells. Very recently, an ingenious approach harnessing intestinal K-cells as surrogate glucose-responsive insulin producers was demonstrated. In this approach, transgenic mice expressing human insulin under the control of the gastrointestinal inhibitory peptide (GIP) promoter were generated. These mice expressed and secreted insulin from intestinal $\mathrm{K}$ cells in which the GIP promoter is active. Insulin secretion in these mice was glucose-responsive and maintained following streptozotocin treatment, indicating that the $\mathrm{K}$ cells were spared the effects of streptozotocin (83). These data suggest that it may be feasible to target the intestinal cells with vectors encoding the GIP-insulin transgene or by ex vivo engineering of intestinal cells in which glucosesensitive promoters are active driving insulin expression.

\section{EXPANDING $\beta$ CELLS OR $\beta$ CELL SURROGATES}

The considerable genetic manipulations that are required to convert non- $\beta$ cells into efficient glucose-sensing, insulin-secreting cells have led other investigators to consider means of expanding adult or neonatal $\beta$ cells or of harnessing the developmental potential of islet precursor cells to commit them to the $\beta$ cell lineage. Even disregarding possible ethical concerns, the successful isolation of purified islet stem cells obtained from the fetus or neonate has remained elusive. Where precursor cells have been identified, commitment to $\beta$ cells and insulin production has not always been consistent (84-88). Recent data indicate that embryonal stem cells can also assume insulin-producing properties (89). If a stable $\beta$ cell-like phenotype can be maintained for these cells in culture and following transplantation, then they could be a source of renewable surrogates for $\beta$ cells following manipulations to expand them.

Despite the current controversy and the serious ethical issues raised by cloning technology, it is likely that therapeutic cloning, under strict and defined conditions, will find its place in stem cell therapies (90-92). In this regard, a possible means of propagating $\beta$ cells or progenitors, while avoiding the complications involved with the immune response, could entail nuclear transfer approaches. In this method, the nucleus (containing donor DNA) from somatic cells of a patient may be transferred into an enucleated embryonal stem cell that can be expanded into an appropriate $\beta$ cell lineage. However, the issue of autoimmunity will remain. While this is highly speculative at present, the rapid pace of basic work in this area, despite restrictions, will likely yield insight into such manipulations. 
The immortalization of islet cells with a $\beta$ cell phenotype has been attempted and successfully achieved. Insulin production, however, seems to be linked to the terminal differentiation of the cell, an event that is normally reached with growth arrest. This problem has so far limited the utility of cell immortalization. This approach also carries with it the troublesome possibility of oncogenic transformation (93-96).

Although still controversial, there are data indicating that mature human $\beta$ cells can be induced to replicate under the effects of hepatocyte growth factor (HGF) (97-99). However, the limitation of this approach rests on the loss of the differentiation of the induced $\beta$ cell, along with a substantial decrease in insulin production (100). Conditional replication of nonhuman $\beta$ cells has been achieved by placing the simian virus 40 (SV40) $\mathrm{T}$ antigen under the control of an inducible promoter (94). In these studies, $\beta$ cells were able to replicate and to maintain differentiated function under inducible conditions. No data exist on whether such an approach is feasible in human $\beta$ cells.

The propagation of islet precursor cells with subsequent genetic manipulation to commit them to the $\beta$ cell lineage and ultimately to $\beta$ cells has also been considered $(88,101)$. For this approach to become feasible, however, a more complete understanding of the hierarchy of master regulatory transcriptional genes is required. Nevertheless, some progress has been made following the discovery that the absence of pancreatic duodenal homeobox (PDX)1 (also known as IDX-1, IPF-1, STF-1, and IUF-1), a homeodomain transcription factor, results in pancreatic agenesis (102). In addition to differentiation of primitive pancreatic epithelium, PDX-1 appears to be important in glucose-sensitive transcriptional transactivation of the insulin gene and GLUT2, GK, and somatostatin (103-106). Depending on the cell type, PDX-1 overexpression can impart onto it a $\beta$ cell or a $\beta$ cell-like phenotype $(102,107,108)$. Indeed, Ferber et al. (109) demonstrated that the adenoviral gene transfer of a PDX-1 gene into the liver resulted in insulin-expressing cells, although it was unclear whether these cells were glucose-sensitive (109).

The transfer of combinations of genes encoding soluble and intracellular differentiation factors could become feasible once their precise role in the pathway of commitment and differentiation becomes clearer. However, $\beta$ cells have a limited lifespan in vitro. To what extent apoptosis or senescence play a role in this is uncertain. Nonetheless, a better understanding of cell cycle control in $\beta$ cells or neonatal islet cells could lead to the discovery of molecules that could be exploited, in a conditional manner, to promote growth in vivo and maintenance or extension of lifespan, both in vitro and in vivo. Possible means include the transfer of cyclin-dependent kinases, pro-replication and mitotic factors, and/or telomerase to promote expanded cell lifespan, all under regulatable promoters. Such an approach could achieve the expansion of semi-committed or fully committed islet precursor cells or early $\beta$ cells. Combined with xenogeneic donor manipulation, these interventions could provide an almost limitless supply of $\beta$ cells for transplantation.

\section{ISLET OR SURROGATE $\beta$ CELL TRANSPLANTATION}

Whatever the identity of the insulinreplacement cells (intact islets, ex vivo-generated $\beta$ cells, or surrogate $\beta$ cells), unless they are of autologous origin, they will need a defense against allogeneic, xenogeneic, and autoimmune attack. There are two levels at which these defenses can be deployed: (i) extracellularly, by the production and secretion of immunosuppressive and/or anti-apoptotic gene products, and (ii) intracellularly, where antiapoptotic protein production could prevent intracellular pathways triggered by extracellular death ligands. Many approaches have been tested, and all are listed in Table 3.

\section{APPROACHES FOR TYPE 2 DIABETES}

Being the predominant risk factor for insulin resistance, obesity is an important target by which the eventual progression to type 2 diabetes can be prevented. Obesity is, itself, a multifactorial syndrome caused by genetic and envionmental factors. While the simple solutions to obesity are to consume in moderation, avoiding highcalorie foods on a long-term basis, and physical exercise for morbidly obese individuals or in those noncompliant to dietary regimens, gene drugs may be the alternative. The primary objective in these gene drugs would be to reduce satiety levels and to regulate the amount of fat. One of the principal regulators of body fat and a fuel sensor is leptin.

Leptin was initially identified as the gene whose mutated variants resulted in the obese phenotype of obese (ob/ob) mice. Leptin encodes a secreted protein with weight-reducing, satietysuppressive, and insulin- and glucoselowering effects (110-114). In a small group of morbidly obese humans, the leptin gene was also found to be mutated, but evidence suggests that almost all forms of obesity in humans are not due to leptin defects (115-118). A series of studies demonstrated that viral gene transfer of leptin to rodent models of obesity was effective in accelerating weight reduction, decreased adipocyte and fat deposits, enhanced fatty acid oxidation, and lowered expression of lipogenic enzymes (119-122). Moreover, a single intramuscular injection of adeno-associated virus (AAV) encoding leptin into ob/ob mice was able to achieve a long-term normalization of metabolic abnormalities, such as impaired glucose tolerance, insulin resistance, hyperglycemia, and lethargy (123). In instances where no leptin receptor defects are detected, leptin gene transfer may prove beneficial, at least to prevent or delay the onset of obesity as a preventative measure against obesity-induced insulin resistance, which precedes type 2 diabetes. Leptin, acting at the level of the hypothalamus, controls a very complex satiety system and, in this regard, leptin expression could be targeted to tissues in which feedback to the hypothalamus and the pituitary occurs in response to feeding.

The observation that the ratio of leptin in the cerebrospinal fluid to serum in obese individuals is higher compared to normal controls suggests that most 
obese individuals do not have defects in the leptin gene and are resistant to its effects either because of a leptin receptor or leptin transport defect (124). These data indicate that alternative strategies aimed at bypassing the hypothalamic targets of leptin thought to be resistant to leptin are necessary and, in this regard, a better objective could be the reestablishment of insulin sensitivity in obese individuals. Identically, such an objective is desired in nonobese insulin-resistant individuals.

\section{Reestablishment of Insulin Sensitivity}

Insulin insensitivity is one of the main characteristics of type 2 diabetics and is associated with increased $\beta$ cell insulin secretion along with hyperinsulinemia. Eventually, $\beta$ cell exhaustion is thought to occur, which results in overt hyperglycemia. Consequently, insulin resistance can be thought of as two impairments whose temporal relationship is not fully clear: peripheral insulin insensitivity with $\beta$ cell compensation, culminating in $\beta$ cell exhaustion (125-127). Whatever the temporal order, the reestablishment of peripheral insulin sensitivity is paramount to prevent $\beta$ cell exhaustion; therefore, strategies aimed at bypassing defects in insulin sensitivity in peripheral tissues (skeletal muscle, adipose, and liver) or to promote glucose uptake and utilization in the periphery must be considered as a first approach in gene therapy strategies.

The major glucose transporter in the periphery is GLUT-4, and studies with transgenic mice indicate that GLUT-4 expression in peripheral tissues could be one way to prevent or ameliorate insulin resistance. Leptinresistant, diabetic $(\mathrm{db} / \mathrm{db})$ mice (whose genetic defect is in the leptin receptor gene), transgenic for the human GLUT-4 transgene, exhibited reduced fasting and nonfasting plasma glucose levels, improved glucose disposal, and insulin-sensitive, glucose-responsive translocation of GLUT-4 to the cell surface (128). In high-fat fed mice where GLUT-4 expression was driven by the fatty acid binding protein aP2 promoter, an adipocyte-specific promoter, a slight improvement in glucose tolerance and increased transport in adipocytes and adipocyte hyperplasia was observed. That the improvement of glucose tolerance was not major was thought to be due to the absence of the GLUT-4 transgene in skeletal muscle, the major tissue of glucose utilization $(129,130)$. Improvements in glucose tolerance and insulin sensitivity were achieved in transgenic mice where GLUT-4 was driven by skeletal muscle-specific promoters. Hansen et al. (131) demonstrated that glucose 
transport into skeletal muscle was significantly increased and insulin-sensitive compared to nontransgenic controls, and, moreover, glycolysis and glycogen synthesis were enhanced in isolated skeletal muscle (131). Additionally, in another transgenic mouse model deficient in GLUT-4, in which GLUT-4 was expressed under the control of the myosin light-chain promoter, the uptake of a synthetic glucose analogue and the actions of insulin were enhanced and restored to normal levels in vivo (132). In a heterozygous GLUT-4 knock-out mouse model, complementation of the gene in skeletal muscle was able to restore insulin sensitivity and prevented a diabetic phenotype (133).

Overexpression of the insulin recep- tor along with GLUT-4 and insulin receptor-downstream signal transducers such as the insulin receptor substrate (IRS) proteins could be another means of restoring normal insulin sensitivity. The rationale for this derives from studies in homozygous or heterozygous transgenic mice deficient for the insulin receptor, IRS-1 and IRS-2 (134). Muscle-specific insulin receptor knock-out mice are insensitive to insulin in muscle but not in liver or adipose, whereas $\beta$ cell-specific insulin receptor knockout mice exhibit an impaired response to glucose, yet are sensitive to insulin in the periphery. However, IRS-1 and IRS-2 knock-out mice are hyperinsulinemic with a mild to severe diabetes where the insulin insensitivity is at the level of muscle and adipose cells in
IRS-1 knock-outs and at the level of liver in IRS-2 knock-outs (134). Ueki et al. (135) demonstrated an almost complete restoration of normal glucose sensitivity in IRS-1-deficient mice injected systemically with an adenovirus encoding IRS-1. Other genes that have been transferred to skeletal muscle include GK using an adenoviral vector in vitro. In that study, an increase in glucose uptake was noted, independently of insulin stimulation, as well as a glucose concentration-dependent accumulation of glucose in skeletal muscle (136). In a follow-up study, the same group demonstrated that adenoviral gene transfer of GK to hepatocytes from Zucker diabetic rats (one rodent model of obesity and insulin resistance) was able to promote normal glucose

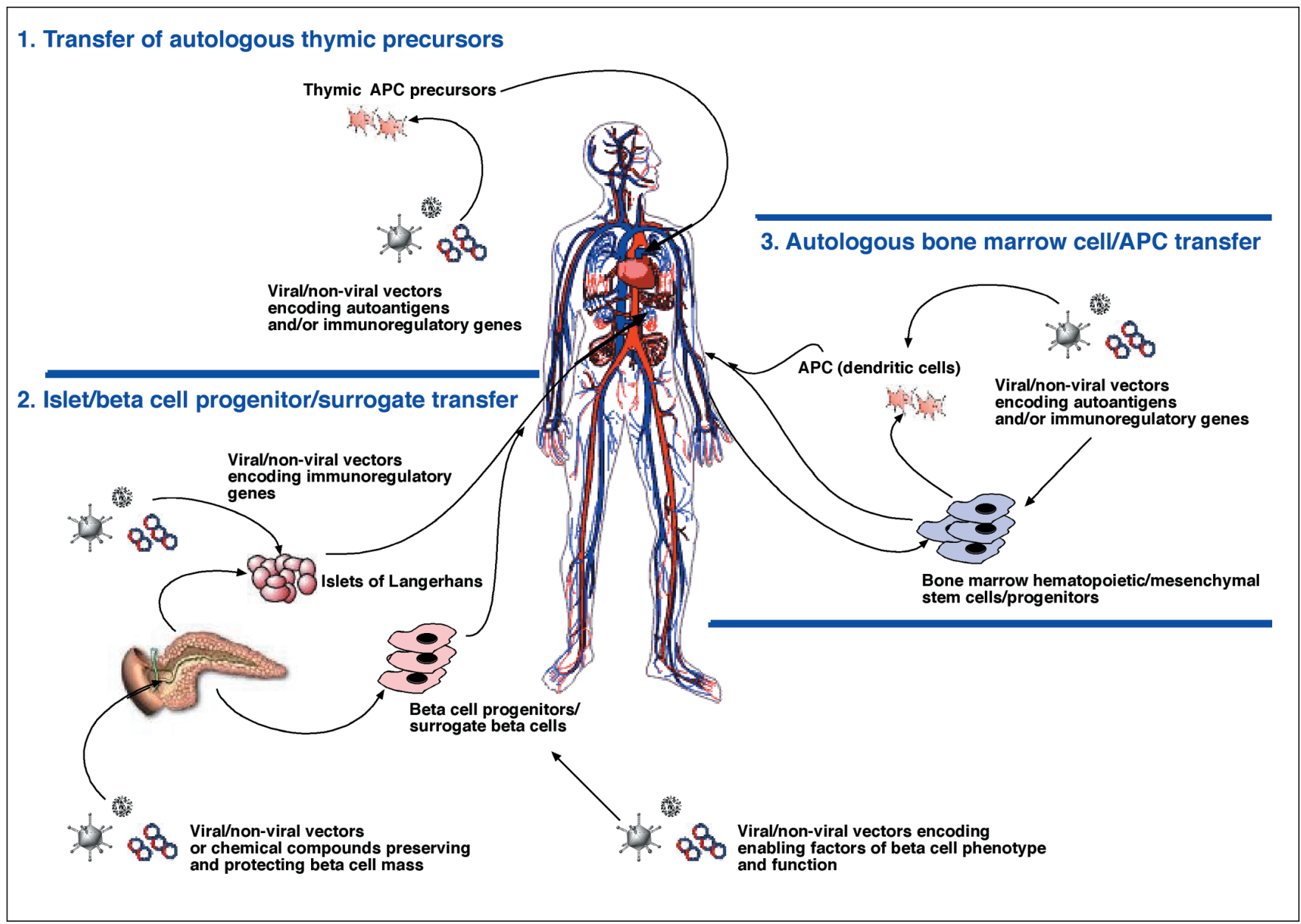

Figure 2. Gene and cell therapy strategies to promote islet allograft/xenograft survival and/or prevent diabetes. Several strategies can be employed alone or in combination: (i) gene transfer of immunoregulatory molecules to autologous cells that can modulate immunoregulatory networks (such as dendritic cells); (ii) gene transfer of cytoprotective genes to allogeneic or xenogeneic islets that will be subsequently transplanted; (iii) protection of $\beta$ cell mass and function during the isolation phase of islets; (iv) gene transfer of factors that promote a $\beta$ cell phenotype to $\beta$ cell progenitors or surrogate cells; $(v)$ and the direct transfer of vectors encoding immunoregulatory molecules into a susceptible or recent-onset patient. 
uptake and conversion to glycogen. More recently, in vivo, transduction of newborn rat skeletal muscle with adenovirus-GK achieved an increase in glucose uptake and ameliorated total body glucose tolerance (137). Finally, Etgen et al. (138) used an adenovirus encoding human protein kinase C-zeta to transduce rat skeletal muscle in vivo. Protein kinase C-zeta is believed to be a constituent of the insulin receptor signaling pathway, and, in that study, the investigators observed enhanced glucose uptake in the skeletal muscle of Zucker rats (138).

Thiazolidinediones are a class of glucose-lowering agents that act to increase insulin sensitivity. Their action is at the level of peroxisome proliferator-activated receptor $\gamma$ (PPAR $\gamma)$, a member of the nuclear transcription family of proteins, although PPAR $\gamma$ independent activities have also been observed (127). Intriguingly, heterozygous knock-out mice for PPAR $\gamma$ do not develop insulin resistance, but, in contrast, display enhanced insulin sensitivity (127). This and other observations suggest that the genetic inhibition of PPAR $\gamma$ activity could prevent insulin resistance, and an approach could be the targeting of dominant-negative variants of PPAR $\gamma$ to insulin-sensitive tissues such as skeletal muscle or adipose.

The activity of cytokines on insulin resistance has been well documented. Tumor necrosis factor- $\alpha$ (TNF $\alpha)$ in particular induces insulin resistance in vitro and in vivo. Cheung et al. (139) demonstrated that systemic gene transfer of a soluble TNF receptor-Fc transgene using an adenoviral vector in Zucker rats enhanced the peripheral insulin sensitivity and suppressed hepatic glucose output (139). It has been suggested that other cytokines such as interleukin (IL)-1 $\beta$ and IL- 6 might be involved in insulin resistance, and targeting their binding to receptors using soluble receptor or antagonist decoy strategy might be beneficial.

\section{Insulin Replacement}

Where peripheral insulin sensitivity is normal and the defect lies at the level of the $\beta$ cell, $\beta$ cell augmentation or replacement strategies may overcome the endogenous defect(s). An approach could be the transplantation of allogeneic islets or the engineering of surrogate $\beta$ cells. Additionally, the identification of $\beta$ stem or progenitor cells is also an area that is promising (140$145)$, especially in light of recent discoveries that bone marrow-derived cells can be made to differentiate into neuronal and muscular cells (146). In the event that the donor is allogeneic, some degree of immunosuppression will be required, and approaches for these strategies have been discussed in an earlier section.

\section{EDUCATING THE IMMUNE SYSTEM}

Type 1 diabetes mellitus is perhaps one of several autoimmune diseases where it may be possible to induce tolerance. The autoimmunity is directed against $\beta$ cells, which suggests that one or more molecules expressed by $\beta$ cells may be employed to tame the immune system. There are some lines of evidence that support the concept that insulin may be an important $\beta$ cell protein to which developing $\mathrm{T}$ cells failed to be educated. First, are the genetic data, where the insulin locus has been linked to type 1 diabetes (147-151). The second line of evidence in support of insulin as an important autoantigen is the demonstration of circulating autoantibodies and, more recently, an insulin-peptide-reactive cytotoxic $\mathrm{T}$ cell clone that was isolated from the islet infiltrate of young NOD mice (152, 153). While insulin remains a strong contender, there is very good evidence in support of other putative antigens such as glutamic acid decarboxylase (GAD) and IA-2 $(1,2)$. These other proteins, however, are expressed in a variety of other nonendocrine cells and 
tissues, and it is unclear how they may specifically contribute in type 1 diabetes autoreactivity (154).

If, indeed, type 1 diabetes is the result of a failure to delete lymphocytes in the thymus that would normally recognize $\beta$ cell antigens, then it is reasonable to propose that thymic over-expression of putative autoantigens in early life, before the onset of type $1 \mathrm{di}$ abetes in individuals deemed at high risk, could prevent the disease by genetic screening criteria. This line of reasoning was initially adopted for studying diabetes in the NOD mouse as well as in the BioBreeding (BB) rat, two rodent models whose diabetes-related immunopathology is considered to be quite similar to that in humans. In NOD mice, the expression of a proinsulin transgene controlled by the MHC class II promoter, resulting in the intrathymic expression of insulin, was able to prevent diabetes (155). This outcome was also achieved in BB rats and in young NOD mice by the intrathymic injection of islet extracts (156-160). In these studies, Posselt et al. (156-158) suggested that tolerance occurred as a consequence of the deletion of islet-reactive thymocytes. The intrathymic injection of insulin B-chain or the $65-\mathrm{kDa}$ variant of GAD into young NOD mice was also able to suppress type 1 diabetes onset (161). However, it is unclear whether this approach will work in post-pubescent humans because of a lack of knowledge concerning thymic delivery. More important is the persistence of the vector for the entire lifetime of the individual and the risks associated with anti-vector response in vivo, depending on the choice of vector, although recent results suggest that thymic gene delivery using adenoviral vectors is possible and can also result in tolerance to the virus-encoded antigens (162).
A second possibility could be to identify the precursors to thymic antigen-presenting cells and to expand them ex vivo concurrent with engineering them to express one or more autoantigens using several gene delivery vectors. Upon introduction into the patient, these cells are expected to migrate to the thymus to express the autoantigen(s). The caveat to this approach is that this cell therapy will be patient-specific and require the isolation of bone marrow cells from which thymic antigen-presenting cell (APC) precursors could be propagated. There is encouraging evidence that this can be clinically feasible. A third and exciting possibilty is to take advantage of peripherally derived APCs that can be engineered to possess tolerogenic properties, acting peripherally and eliminating or silencing circulating autoreactive $T$ cells. In fact, we and others have demonstrated that this approach can facilitate allogeneic cardiac and islet allograft survival, and a minor modification of this approach could be applied to tolerance to autoantigens (163-166).

Full activation of $\mathrm{T}$ lymphocytes requires a second signal in addition to the interaction between the $\mathrm{T}$ cell receptor (TCR) and the peptide/major histocompatibility complex (MHC) class II complex on an APC (13). This second signal, acting through the CD28 molecule at the surface of T lymphocytes, can be provided by the $\mathrm{B} 7$ molecules, $\mathrm{B} 7-1$ (CD80) and B7-2 (CD86), which are expressed at the surface of APCs. Blockade of CD28-B7 interaction leads to T cell anergy or apoptosis (167). The fusion, CTLA-4Ig, effectively acts as a decoy for B7 molecules and prevents the B7-CD28 interaction. Several studies illustrated in Table 3 demonstrate the feasibility of the gene transfer of this agent to prevent and modulate type 1 diabetes (168-178).

\section{THE CHOICE OF DENDRITIC CELLS AS EDUCATORS}

Although considered potent immunostimulators, dendritic cells (DCs) have recently been shown to possess tolerogenic characteristics under defined conditions. DC tolerogenicity, 
manifested as the suppression of $\mathrm{T}$ cell activation, has been documented in tumor-, allo-, and auto-immunity (179). The conditions that can yield tolerogenic DCs include ultraviolet irradiation and exposure to CTLA-4Ig, transforming growth factor (TGF) $\beta$, or IL-10 (180). How a tolerogenic DC acts to suppress immunoreactivity is not completely understood, but it may involve anergy, a shift to TH2-type responses, apoptosis, or the induction of regulatory cells (179). Myeloid DCs have been genetically modified using adenoviral and retroviral vectors encoding CTLA-4Ig, TGF $\beta$, and IL-10 (180). CTLA-4Ig-expressing DC significantly prolong allograft survival, can induce alloantigen-specific $\mathrm{T}$ cell hyporesponsiveness, and display enhanced survival in nonimmunosuppressed, allogeneic hosts (180). The in vivo presentation of alloantigens by donor or recipient DCs in the absence of co-stimulation, along with the local production of immunosuppressive molecules such as TGF $\beta$, could likely promote the inhibition of anti-donor reactivity and promote tolerance induction with no major systemic immunosuppression. DCs engineered to express vIL-10 following retroviral gene transfer produce high levels of vIL-10 in vitro, exhibit marked reduction in cell surface MHC and co-stimulatory molecule expression, decrease $\mathrm{T}$ cell allostimulation, and promote the induction of $\mathrm{T}$ cell hyporesponsiveness (181). Genetically engineered DCs may be used to prevent islet allograft rejection because they are able to manipulate anti-donor and/or autoantigen immunoreactivity. Alternatively, if recent observations that show islet-specific molecule gene expression in peripheral lymphoid organs can be confirmed in APCs (182) such as bone marrow-derived DCs (unpublished observations), one can envision infusing engineered DCs that lack co-stimulatory capability but that express islet-specific genes (e.g., GAD65 or insulin) into prediabetic or early-onset diabetic patients, with the objective of inducing autoantigen-specific tolerance.

A related approach can be similar to that described by Zhang et al. (183), who have engineered DCs to express Fas ligand as a means of inducing tol- erance (183). Peripheral blood mononuclear cells can be cultured ex vivo, and DCs can be propagated using a cytokine cocktail (184). These DCs, or their monocyte precursors, could be engineered with several different gene delivery vehicles, each of which alone or as a multi-cistronic construct could encode putative autotantigens along with proteins that can induce the apoptosis of T cells with TCR that recognize the over-expressed antigen peptides or could silence autoreactive $\mathrm{T}$ cells. One can envision, for example, DCs expressing GAD and Fas ligand or CTLA-4Ig. In the first instance, the $T$ cells with TCR specific for GAD epitopes, upon reacting with the DCs, will encounter Fas ligand, and, as activated $\mathrm{T}$ cells expressing Fas, will be induced to undergo apoptosis. In the other instance, GAD-reactive $\mathrm{T}$ cells will be unable to receive the CD80, CD86 co-stimulatory signal, because of the CTLA-4Ig produced by the DCs and will therefore be unable to proliferate. Indeed, studies in allogeneic transplant models have demonstrated that DCs that are engineered to express TGF $\beta$ or CTLA-4Ig can induce donorspecific hyporeactivity in vitro and can significantly prolong allogeneic heart transplants when injected in vivo $(180,185)$. More recently, DCs have been treated ex vivo with oligodeoxyribonucleotide decoys to nuclear factor $\kappa \mathrm{B}(\mathrm{NF}-\kappa \mathrm{B})$, an important maturational transcriptional mediator in DCs and, when injected into an allogeneic host, were able to prolong the survival of an allogeneic heart (166). It is likely that other transcriptional pathways in APCs could be exploited by decoy nucleotide strategies to present autoantigen in the absence of co-stimulatory signals or in the presence of death ligands to silence or kill autoreactive $T$ cells

\section{IMMUNOREGULATORY VACCINES}

Several studies have shown that the injection of DNA plasmid vectors encoding immunosuppressive genes, such as TGF $\beta$, and a soluble interferon (IFN) $\gamma$ receptor into the muscle of NOD mice can reduce the incidence of 
type 1 diabetes (186-188). The mechanism for protection is unclear but may involve the suppression of maturation of APCs in the periphery and the suppression of autoreactive $\mathrm{T}$ cell activity before and during insulitis. Furthermore, the incomplete penetrance of the protection could very well be due to the nature of the plasmid DNA vector and its low persistence, especially at the sites of injection. Another critical factor that may have influenced this exciting approach is the nature of the cells that take up the plasmid vector. It is possible that the immunosuppressive transgene was expressed in migratory APCs at the site of injection of the mice in which protection was achieved, which then could deliver the immunosuppressive protein to peripheral lymphoid organs. In the animals in which no protection was achieved, the vector may have been taken up by other cells such as skeletal muscle and fibroblasts, which, by their nonmigratory character, confined the expression of the immunosuppressive transgene locally at the site of injection. To enhance this approach, one could target vectors to APCs either by pseudotyping with envelopes engineered to possess ligands for APC-specific receptors or in cationic formulations into which these APC-specific proteins are conjugated. Bioballistic gene delivery may offer advantages for this approach over injection, as several studies indicate that Langerhans cells and migratory APCs are more efficiently engineered to express a transgene by gene gun delivery $(189,190)$. Finally, in theory, one could also isolate Langerhans cell progenitors from a patient, expand them ex vivo, engineer them in a manner similar to that described above (i.e., multicistronic vectors encoding autoantigen, along with immunoregulatory gene products) and introduce them subcutaneously, where they will migrate to the peripheral lymph nodes to engage autoreactive $T$ cells.

While manipulating APCs to express autoantigens in a tolerogenic context may be one means of promoting tolerance, an alternative method could involve the engineering of thymic APCs to express human leukocyte antigen (HLA) alleles that are not associat- ed with type I diabetes. The expression of HLA DQ and DR alleles conferring susceptibility, for example, could be suppressed by antisense approaches, followed by the supplementation of the thymus with thymic APCs, engineered ex vivo to express nondiabetogenic class II HLA alleles. The rationale for this approach lies in the observations of Singer et al. (191), who have demonstrated that type 1 diabetes was prevented in transgenic NOD mice expressing a nondiabetogenic MHC class II molecule in place of the diabetogenic I-Ag7. We encapsulate all the approaches reviewed and proposed here in the cartoon in Figure 2.

\section{GENES, CELLS, OR BOTH?}

It is premature to make conclusive statements about the future clinical utility of gene therapy for disorders of glucose metabolim, especially diabetes mellitus. Despite the current priority shift from gene transfer to stem cells, more questions and concerns have been raised regarding stem cells compared to gene therapy approaches. In fact, a very recent report appears to refute many pivotal discoveries of putative insulin-producing stem cells (192) and outlines several critical tests that this area of investigation must pass before further consideration. Gene therapy, on the other hand, has passed the conceptual hurdles and has demonstrated strong potential for clinical translation, either as a means of facilitating islet transplantation and/or educating the immune system to accept allogeneic cells and tissues. More emphasis should be placed on the translational research in this realm, with a crucial evaluation of multigenic approaches in low-immunogenicity vectors. Ultimately, we predict that ex vivo engineering of cells will yield the first successful translation of promising animal studies into the clinic.

\section{ACKNOWLEDGMENTS}

The authors' work has, in part, been supported by a Center grant (no. 41999-845) from the Juvenile Diabetes Research Foundation.

\section{REFERENCES}

1.Bach, J.F. 1994. Insulin-dependent diabetes mellitus as an autoimmune disease. Endocr. Rev. 15:516-542.

2.Eisenbarth, G.S. 1993. Molecular aspects of the etiology of type I diabetes mellitus. J. Diabetes Complications 7:142-150.

3.Velho, G. and P. Froguel. 1997. Genetic determinants of non-insulin-dependent diabetes mellitus: strategies and recent results. Diabetes Metab. 23:7-17

4.Robertson, R.P. 1989. Type II diabetes, glucose "non-sense," and islet desensitization. Diabetes 38:1501-1505.

5.Chan, J.M., E.B. Rimm, G.A. Colditz, M.J. Stampfer, and W.C. Willett. 1994. Obesity, fat distribution, and weight gain as risk factors for clinical diabetes in men. Diabetes Care 17:961-969.

6.DeFronzo, R.A. and E. Ferrannini. 1991. Insulin resistance. A multifaceted syndrome responsible for NIDDM, obesity, hypertension, dyslipidemia, and atherosclerotic cardiovascular disease. Diabetes Care 14:173-194.

7.Dowse, G.K., P.Z. Zimmet, H. Gareeboo, K. George, M.M. Alberti, J. Tuomilehto, C.F. Finch, P. Chitson, et al. 1991. Abdominal obesity and physical inactivity as risk factors for NIDDM and impaired glucose tolerance in Indian, Creole, and Chinese Mauritians. Diabetes Care 14:271-282.

8.DeFronzo, R.A. 2000. Pharmacologic therapy for type 2 diabetes mellitus. Ann. Intern. Med. 133:73-74.

9.Abdallah, M.P. and K. Hirbli. 1999. Pharmacologic treatment of type 2 diabetes mellitus: realities and perspectives. J. Med. Liban. 47:233-237.

10.McCormick, M. and L. Quinn. 2002. Treatment of type 2 diabetes mellitus: pharmacologic intervention. J. Cardiovasc. Nurs. 16:55-67.

11. The Diabetes Control and Complications Trial Research Group. 1997. Clustering of long-term complications in families with diabetes in the diabetes control and complications trial. Diabetes 46:1829-1839.

12.Giannoukakis, N., M. Pietropaolo, and M. Trucco. 2002. Genes and engineered cells as drugs for type I and type II diabetes mellitus therapy and prevention. Curr. Opin. Investig. Drugs 3:735-751.

13.Giannoukakis, N., W.A. Rudert, P.D. Robbins, and M. Trucco. 1999. Targeting autoimmune diabetes with gene therapy. Diabetes 48:2107-2121.

14.Friday, R.P., M. Trucco, and M. Pietropaolo. 1999. Genetics of Type 1 diabetes mellitus. Diabetes Nutr. Metab. 12:3-26.

15.Eisenbarth, G. 1991. Prediction and prevention strategies in type I diabetes. Mt. Sinai J. Med. 58:274-279.

16.Pietropaolo, M., E. Barinas-Mitchell, S.L. Pietropaolo, L.H. Kuller, and M. Trucco. 2000. Evidence of islet cell autoimmunity in elderly patients with type 2 diabetes. Diabetes 49:32-38.

17.Froguel, P. 1996. Glucokinase and MODY: from the gene to the disease. Diabet. Med. 13:S96-S97.

18.Clement, K. 1999. Leptin and the genetics of obesity. Acta Paediatr. Suppl. 88:51-57. 
19.Mantzoros, C.S. 1999. The role of leptin in human obesity and disease: a review of current evidence. Ann. Intern. Med. 130:671-680.

20.Storlien, L.H., L.A. Baur, A.D. Kriketos, D.A. Pan, G.J. Cooney, A.B. Jenkins, G.D. Calvert, and L.V. Campbell. 1996. Dietary fats and insulin action. Diabetologia 39:621631

21.Boden, G. 1997. Role of fatty acids in the pathogenesis of insulin resistance and NIDDM. Diabetes 46:3-10.

22.Roden, M., T.B. Price, G. Perseghin, K.F. Petersen, D.L. Rothman, G.W. Cline, and G.I. Shulman. 1996. Mechanism of free fatty acid-induced insulin resistance in humans. J. Clin. Invest. 97:2859-2865.

23.Shepherd, P.R. and B.B. Kahn. 1999. Glucose transporters and insulin action-implications for insulin resistance and diabetes mellitus. N. Engl. J. Med. 341:248-257.

24.Robbins, P.D., H. Tahara, and S.C. Ghivizzani. 1998. Viral vectors for gene therapy. Trends Biotechnol. 16:35-40.

25.Robbins, P.D. and S.C. Ghivizzani. 1998. Viral vectors for gene therapy. Pharmacol. Ther. 80:35-47.

26.Stone, D., A. David, F. Bolognani, P.R. Lowenstein, and M.G. Castro. 2000. Viral vectors for gene delivery and gene therapy within the endocrine system. J. Endocrinol
164:103-118

27.Palu, G, C. Parolin, Y. Takeuchi, and M. Pizzato. 2000. Progress with retroviral gene vectors. Rev. Med. Virol. 10:185-202.

28. Walther, W. and U. Stein. 2000. Viral vectors for gene transfer: a review of their use in the treatment of human diseases. Drugs 60:249 271.

29.Vigna, E. and L. Naldini. 2000. Lentiviral vectors: excellent tools for experimental gene transfer and promising candidates for gene therapy. J. Gene Med. 2:308-316.

30.Hu, W.S. and V.K. Pathak. 2000. Design of retroviral vectors and helper cells for gene therapy. Pharmacol. Rev. 52:493-511.

31.Smith-Arica, J. R. and J.S. Bartlett. 2001 Gene therapy: recombinant adeno-associated virus vectors. Curr. Cardiol. Rep. 3:43-49.

32.Pandya, S., E. Klimatcheva, and V. Planelles. 2001. Lentivirus and foamy virus vectors: novel gene therapy tools. Expert Opin. Biol. Ther. 1:17-40.

33.Liu, F. and L. Huang. 2002. Development of non-viral vectors for systemic gene delivery. J. Control Release 78:259-266.

34.Lotze, M.T. and T.A. Kost. 2002. Viruses as gene delivery vectors: application to gene function, target validation, and assay development. Cancer Gene Ther. 9:692-699.

35.Murphy, J.E., S. Zhou, K. Giese, L.T.
Williams, J.A. Escobedo, and V.J. Dwarki. 1997. Long-term correction of obesity and diabetes in genetically obese mice by a single intramuscular injection of recombinant adenoassociated virus encoding mouse leptin. Proc. Natl. Acad. Sci. USA 94:13921-13926.

36.Sugiyama, A., S. Hattori, S. Tanaka, F. Isoda, S. Kleopoulos, M. Rosenfeld, M. Kaplitt, H. Sekihara, et al. 1997. Defective adenoassociated viral-mediated transfection of insulin gene by direct injection into liver parenchyma decreases blood glucose of diabetic mice. Horm. Metab. Res. 29:599-603.

37.Yang, Y.W. and R. M. Kotin. 2000. Glucoseresponsive gene delivery in pancreatic Islet cells via recombinant adeno-associated viral vectors. Pharm. Res. 17:1056-1061.

38.Kapturczak, M.H., T. Flotte, and M.A. Atkinson. 2001. Adeno-associated virus (AAV) as a vehicle for therapeutic gene delivery: improvements in vector design and viral production enhance potential to prolong graft survival in pancreatic islet cell transplantation for the reversal of type 1 diabetes. Curr. Mol. Med. 1:245-258

39.Yang, Z., M. Chen, R. Wu, L.B. Fialkow, J.S. Bromberg, M. McDuffie, A. Naji, and J.L. Nadler. 2002. Suppression of autoimmune diabetes by viral IL-10 gene transfer. J. Immunol. 168:6479-6485. 
40.Jindal, R.M., M. Karanam, and R. Shah. 2001. Prevention of diabetes in the NOD mouse by intra-muscular injection of recombinant adeno-associated virus containing the preproinsulin II gene. Int. J. Exp. Diabetes Res. 2:129-138.

41.Jacobs, A., X.O. Breakefield, and C. Fraefel. 1999. HSV-1-based vectors for gene therapy of neurological diseases and brain tumors: part II. Vector systems and applications. Neoplasia 1:402-416.

42.Burton, E.A., D.J. Fink, and J.C. Glorioso. 2002. Gene delivery using herpes simplex virus vectors. DNA Cell Biol. 21:915-936.

43.Burton, E.A., S. Huang, W.F. Goins, and J.C. Glorioso. 2003. Use of the herpes simplex viral genome to construct gene therapy vectors. Methods Mol. Med. 76:1-31.

44.Burton, E.A., Q. Bai, W.F. Goins, and J.C. Glorioso. 2002. Replication-defective genomic herpes simplex vectors: design and production. Curr. Opin. Biotechnol. 13:424-428.

45.Goins, W.F., D.M. Krisky, D.P. Wolfe, D.J. Fink, and J.C. Glorioso. 2002. Development of replication-defective herpes simplex virus vectors. Methods Mol. Med. 69:481-507.

46.Glorioso, J.C. and D.J. Fink. 2002. Use of HSV vectors to modify the nervous system. Curr. Opin. Drug Discov. Devel. 5:289-295.

47.Kamiya, H., H. Tsuchiya, J. Yamazaki, and H. Harashima. 2001. Intracellular trafficking and transgene expression of viral and non-viral gene vectors. Adv. Drug Deliv. Rev. 52:153164.

48.Schatzlein, A.G. 2001. Non-viral vectors in cancer gene therapy: principles and progress. Anticancer Drugs 12:275-304.

49.Goedegebuure, P.S. and T.J. Eberlein. 1997. Vaccine trials for the clinician: prospects for viral and non-viral vectors. Oncologist 2:300310 .

50.Cristiano, R.J. 1998. Viral and non-viral vectors for cancer gene therapy. Anticancer Res. 18:3241-3245

51.Fricker, J. 1998. Combining strategies to improve non-viral vectors. Mol. Med. Today 4:323

52.Embury, J., D. Klein, A. Pileggi, M. Ribeiro, S. Jayaraman, R.D. Molano, C. Fraker, N. Kenyon, et al. 2001. Proteins linked to a protein transduction domain efficiently transduce pancreatic islets. Diabetes 50:1706-1713.

53.Rehman, K.K., S. Bertera, R. Bottino, A.N. Balamurugan, J.C. Mai, Z. Mi, M. Trucco, and P.D. Robbins. 2003. Protection of islets by in situ peptide mediated transduction of the Ikappa B kinase (IKK) inhibitor nemo binding domain (NBD) peptide. J. Biol. Chem. 278:9862-9867.

54.Eguchi, A., T. Akuta, H. Okuyama, T. Senda, H. Yokoi, H. Inokuchi, S. Fujita, T. Hayakawa, et al. 2001. Protein transduction domain of HIV-1 Tat protein promotes efficient delivery of DNA into mammalian cells. J. Biol. Chem. 276:26204-26210.

55.Mai, J.C., H. Shen, S.C. Watkins, T. Cheng, and P.D. Robbins. 2002. Efficiency of protein transduction is cell type-dependent and is enhanced by dextran sulfate. J. Biol. Chem. 277:30208-30218.

56.Mi, Z., J. Mai, X. Lu, and P.D. Robbins. 2000. Characterization of a class of cationic peptides able to facilitate efficient protein transduction in vitro and in vivo. Mol. Ther. 2:339-347

57.Fawell, S., J. Seery, Y. Daikh, C. Moore, L.L. Chen, B. Pepinsky, and J. Barsoum. 1994. Tat-mediated delivery of heterologous proteins into cells. Proc. Natl. Acad. Sci. USA 91:664-668.

58.Nagahara, H., A.M. Vocero-Akbani, E.L. Snyder, A. Ho, D.G. Latham, N.A. Lissy, M. Becker-Hapak, S.A. Ezhevsky, et al. 1998. Transduction of full-length TAT fusion proteins into mammalian cells: TAT-p27Kip1 induces cell migration. Nat. Med. 4:1449-1452.

59.Ilan, Y., P. Attavar, M. Takahashi, A. Davidson, M.S. Horwitz, J. Guida, N.R. Chowdhury, and J.R. Chowdhury. 1996. Induction of central tolerance by intrathymic inoculation of adenoviral antigens into the host thymus permits long-term gene therapy in Gunn rats. J. Clin. Invest. 98:2640-2647.

60.Bosch, P., D.S. Musgrave, J.Y. Lee, J. Cummins, T. Shuler, T.C. Ghivizzani, T. Evans, T.D. Robbins, et al. 2000. Osteoprogenitor cells within skeletal muscle. J. Orthop. Res. 18:933-944.

61.Lee, J.Y., Z. Qu-Petersen, B. Cao, S. Kimura, R. Jankowski, J. Cummins, A. Usas, C. Gates, et al. 2000. Clonal isolation of musclederived cells capable of enhancing muscle regeneration and bone healing. J. Cell Biol. 150:1085-1100.

62.Vollenweider, F., J.C. Irminger, and P.A. Halban. 1993. Substrate specificity of proinsulin conversion in the constitutive pathway of transfected FAO (hepatoma) cells. Diabetologia 36:1322-1325.

63.Vollenweider, F., J.C. Irminger, D.J. Gross, L. Villa-Komaroff, and P.A. Halban. 1992. Processing of proinsulin by transfected hepatoma (FAO) cells. J. Biol. Chem. 267:14629-14636.

64.Groskreutz, D.J., M.X. Sliwkowski, and C.M. Gorman. 1994. Genetically engineered proinsulin constitutively processed and secreted as mature, active insulin. J. Biol. Chem. 269:6241-6245.

65.Mitanchez, D., R. Chen, J.F. Massias, A. Porteu, A. Mignon, X. Bertagna, and A. Kahn. 1998. Regulated expression of mature human insulin in the liver of transgenic mice. FEBS Lett. 421:285-289.

66.Mitanchez, D., B. Doiron, R. Chen, and A. Kahn. 1997. Glucose-stimulated genes and prospects of gene therapy for type I diabetes. Endocr. Rev. 18:520-540

67.Thule, P.M. and J.M. Liu. 2000. Regulated hepatic insulin gene therapy of STZ-diabetic rats. Gene Ther. 7:1744-752.

68.Thule, P.M., J. Liu, and L.S. Phillips. 2000. Glucose regulated production of human insulin in rat hepatocytes. Gene Ther. 7:205-214.

69.Lee, H.C., S.J. Kim, K.S. Kim, H.C. Shin, and J.W. Yoon. 2000. Remission in models of type 1 diabetes by gene therapy using a singlechain insulin analogue. Nature 408:483-488.

70.Chen, R., M.L. Meseck, and S.L. Woo. 2001. Auto-regulated hepatic insulin gene expression in type 1 diabetic rats. Mol. Ther. 3:584-590.

71.Chen, R., M. Meseck, R.C. McEvoy, and S.L. Woo. 2000. Glucose-stimulated and selflimiting insulin production by glucose 6 - phos- phatase promoter driven insulin expression in hepatoma cells. Gene Ther. 7:1802-1809.

72.Iynedjian, P.B., D. Jotterand, T. Nouspikel, M. Asfari, and P.R. Pilot. 1989. Transcriptional induction of glucokinase gene by insulin in cultured liver cells and its repression by the glucagon-cAMP system. J. Biol. Chem. 264:21824-21829

73.Iynedjian, P.B., P.R. Pilot, T. Nouspikel, J.L. Milburn, C. Quaade, S. Hughes, C. Ucla, and C.B. Newgard. 1989. Differential expression and regulation of the glucokinase gene in liver and islets of Langerhans. Proc. Natl. Acad. Sci. USA 86:7838-7842.

74.Mitanchez, D., B. Doiron, R. Chen, and A. Kahn. 1997. Glucose-stimulated genes and prospects of gene therapy for type I diabetes. Endocr. Rev. 18:520-540.

75.Liu, J.S., E.A. Park, A.L. Gurney, W.J. Roesler, and R.W. Hanson. 1991. Cyclic AMP induction of phosphoenolpyruvate carboxykinase (GTP) gene transcription is mediated by multiple promoter elements. J. Biol Chem. 266:19095-19102.

76.Klemm, D.J., W.J. Roesler, J.S. Liu, E.A Park, and R.W. Hanson. 1990. In vitro analysis of promoter elements regulating transcription of the phosphoenolpyruvate carboxykinase (GTP) gene. Mol. Cell Biol. 10:480-485

77.Moore, H.P., M.D. Walker, F. Lee, and R.B. Kelly. 1983. Expressing a human proinsulin cDNA in a mouse ACTH-secreting cell. Intracellular storage, proteolytic processing, and secretion on stimulation. Cell 35:531-538

78.Smeekens, S.P., AG. Montag, G. Thomas, C. Albiges-Rizo, R. Carroll, M. Benig, L.A. Phillips, S. Martin, et al. 1992. Proinsulin processing by the subtilisin-related proprotein convertases furin, PC2, and PC3. Proc. Natl. Acad Sci. USA 89:8822-8826.

79.Hughes, S.D., C. Quaade, J.H. Johnson, S Ferber, and C.B. Newgard. 1993. Transfection of AtT-20ins cells with GLUT-2 but not GLUT-1 confers glucose-stimulated insulin secretion. Relationship to glucose metabolism. J. Biol. Chem. 268:15205-15212.

80.Scharfmann, R., J.H. Axelrod, and I.M Verma. 1991. Long-term in vivo expression of retrovirus-mediated gene transfer in mouse fibroblast implants. Proc. Natl. Acad. Sci. USA 88:4626-4630.

81.Lipes, M.A., E.M. Cooper, R. Skelly, C.J. Rhodes, E. Boschetti, G.C. Weir, and A.M. Davalli. 1996. Insulin-secreting non-islet cells are resistant to autoimmune destruction. Proc. Natl. Acad. Sci. USA 93:8595-8600.

82.Lipes, M.A., A.M. Davalli, and E.M. Cooper. 1997. Genetic engineering of insulin expression in nonislet cells: implications for beta-cell replacement therapy for insulin-dependent diabetes mellitus. Acta Diabetol. 34:2-

83.Cheung, A.T., B. Dayanandan, J.T. Lewis, G.S. Korbutt, R.V. Rajotte, M. Bryer-Ash, M.O. Boylan, M.M. Wolfe, et al. 2000. Glucose-dependent insulin release from genetically engineered K cells. Science 290:1959-1962.

84.Cornelius, J.G., V. Tchernev, K.J. Kao, and A.B. Peck. 1997. In vitro-generation of islets in long-term cultures of pluripotent stem cells from adult mouse pancreas. Horm. Metab. Res. 29:271-277. 
85.Beattie, G.M., J.S. Rubin, M.I. Mally, T. Otonkoski, and A. Hayek. 1996. Regulation of proliferation and differentiation of human fetal pancreatic islet cells by extracellular matrix, hepatocyte growth factor, and cell-cell contact. Diabetes 45:1223-1228.

86.Beattie, G.M., A.D. Lopez, and A. Hayek. 1995. In vivo maturation and growth potential of human fetal pancreases: fresh versus cultured tissue. Transplant. Proc. 27:3343.

87.Beattie, G.M. and A. Hayek. 1994. Outcome of human fetal pancreatic transplants according to implantation site. Transplant. Proc. 26:3299.

88.Beattie, G.M., V. Cirulli, A.D. Lopez, and A. Hayek. 1997. Ex vivo expansion of human pancreatic endocrine cells. J. Clin. Endocrinol. Metab. 82:1852-1856.

89.Lumelsky, N., O. Blondel, P. Laeng, I. Velasco, R. Ravin, and R. McKay. 2001. Differentiation of embryonic stem cells to insulin-secreting structures similar to pancreatic islets. Science 292:1389-1394.

90.Colman, A. and A. Kind. 2000. Therapeutic cloning: concepts and practicalities. Trends Biotechnol. 18:192-196.

91.Kind, A. and A. Colman. 1999. Therapeutic cloning: needs and prospects. Semin. Cell Dev. Biol. 10:279-286.

92.Lanza, R.P., J.B. Cibelli, and M.D. West. 1999. Human therapeutic cloning. Nat. Med. 5:975-977.

93.D'Ambra, R., M. Surana, S. Efrat, R.G. Starr, and N. Fleischer. 1990. Regulation of insulin secretion from beta-cell lines derived from transgenic mice insulinomas resembles that of normal beta-cells. Endocrinology 126:2815-2822.

94.Efrat, S., D. Fusco-DeMane, H. Lemberg, O. al Emran, and X. Wang. 1995. Conditional transformation of a pancreatic beta-cell line derived from transgenic mice expressing a tetracycline-regulated oncogene. Proc. Natl. Acad. Sci. USA 92:3576-3580.

95.Efrat, S. 1998. Cell-based therapy for insulin-dependent diabetes mellitus. Eur. J. Endocrinol. 138:129-133.

96.Fleischer, N., C. Chen, M. Surana, M. Leiser, L. Rossetti, W. Pralong, and S. Efrat. 1998. Functional analysis of a conditionally transformed pancreatic beta-cell line. Diabetes 47:1419-1425.

97.Hayek, A., G.M. Beattie, V. Cirulli, A.D. Lopez, C. Ricordi, and J.S. Rubin. 1995. Growth factor/matrix-induced proliferation of human adult beta-cells. Diabetes 44:1458 1460

98.Otonkoski, T., G.M. Beattie, J.S. Rubin, A.D. Lopez, A. Baird, and A. Hayek. 1994. Hepatocyte growth factor/scatter factor has insulinotropic activity in human fetal pancreatic cells. Diabetes 43:947-953.

99.Otonkoski, T., V. Cirulli, M. Beattie, M.I. Mally, G. Soto, J.S. Rubin, and A. Hayek. 1996. A role for hepatocyte growth factor/scatter factor in fetal mesenchyme- induced pancreatic beta-cell growth. Endocrinology 137:3131-3139.

100.Levine, F. and G. Leibowitz. 1999. Towards gene therapy of diabetes mellitus. Mol. Med. Today 5:165-171.

101.Beattie, G.M., P. Itkin-Ansari, V. Cirulli, G.
Leibowitz, A.D. Lopez, S. Bossie, M.I. Mally, F. Levine, et al. 1999. Sustained proliferation of PDX-1+ cells derived from human islets. Diabetes 48:1013-1019.

102.Habener, J.F. and D.A. Stoffers. 1998. A newly discovered role of transcription factors involved in pancreas development and the pathogenesis of diabetes mellitus. Proc. Assoc. Am. Physicians 110:12-21.

103.Waeber, G., N. Thompson, P. Nicod, and C. Bonny. 1996. Transcriptional activation of the GLUT2 gene by the IPF-1/STF-1/IDX-1 homeobox factor. Mol. Endocrinol. 10:132734.

104.Marshak, S., H. Totary, E. Cerasi, and D. Melloul. 1996. Purification of the beta-cel glucose-sensitive factor that transactivates the insulin gene differentially in normal and transformed islet cells. Proc. Natl. Acad. Sci. USA 93:15057-15062.

105.Shushan, E.B., E. Cerasi, and D. Melloul. 1999. Regulation of the insulin gene by glucose: stimulation of trans- activation potency of human PDX-1 N-terminal domain. DNA Cell Biol. 18:471-479.

106.Watada, H., Y. Kajimoto, J. Miyagawa, T. Hanafusa, K. Hamaguchi, T. Matsuoka, K. Yamamoto, Y. Matsuzawa, et al. 1996. PDX-1 induces insulin and glucokinase gene expressions in alphaTC1 clone 6 cells in the presence of betacellulin. Diabetes 45:18261831

107.Madsen, O.D., J. Jensen, H.V. Petersen, E.E. Pedersen, A. Oster, F.G. Andersen, M.C. Jorgensen, P.B. Jensen, et al. 1997. Transcription factors contributing to the pancreatic beta-cell phenotype. Horm. Metab. Res. 29:265-270.

108.Sander, M. and M.S. German. 1997. The beta cell transcription factors and development of the pancreas. J. Mol. Med. 75:327340 .

109.Ferber, S., A. Halkin, H. Cohen, I. Ber, Y Einav, I. Goldberg, I. Barshack, R. Seijffers, et al. 2000. Pancreatic and duodena homeobox gene 1 induces expression of in sulin genes in liver and ameliorates streptozotocin-induced hyperglycemia. Nat. Med. 6:568-572.

110.Halaas, J.L., K.S. Gajiwala, M. Maffei, S.L. Cohen, B.T. Chait, D. Rabinowitz, R.L. Lallone, S. K. Burley, et al. 1995. Weight-reducing effects of the plasma protein encoded by the obese gene. Science 269:543546.

111.Campfield, L.A., F.J. Smith, Y. Guisez, R. Devos, and P. Burn. 1996. OB protein: a peripheral signal linking adiposity and central neural networks. Appetite 26:302

112.Campfield, L.A., F.J. Smith, Y. Guisez, R. Devos, and P. Burn. 1995. Recombinant mouse OB protein: evidence for a periphera signal linking adiposity and central neura networks. Science 269:546-549.

113.Pelleymounter, M.A., M.J. Cullen, D. Healy, R. Hecht, D. Winters, and M. McCaleb. 1998. Efficacy of exogenous recombinant murine leptin in lean and obese 10- to 12-mo-old female CD-1 mice. Am. J. Physiol. 275:R950-R959.

114.Pelleymounter, M.A., M.J. Cullen, M.B. Baker, R. Hecht, D. Winters, T. Boone, and
F. Collins. 1995. Effects of the obese gene product on body weight regulation in ob/ob mice. Science 269:540-543.

115.Burguera, B., M.E. Couce, J. Long, J. Lamsam, K. Laakso, M.D. Jensen, J.E. Parisi, and R.V. Lloyd. 2000. The long form of the leptin receptor (OB-Rb) is widely expressed in the human brain. Neuroendocrinology 71:187-195.

116.Carlsson, B., K. Lindell, B. Gabrielsson, C. Karlsson, R. Bjarnason, O. Westphal, U. Karlsson, L. Sjostrom, et al. 1997. Obese (ob) gene defects are rare in human obesity. Obes. Res. 5:30-35.

117.Bray, M.S., E. Boerwinkle, and C.L. Hanis. 1996. OB gene not linked to human obesity in Mexican American affected sib pairs from Starr County, Texas. Hum. Genet. 98:590595.

118.Maffei, M., M. Stoffel, M. Barone, B. Moon, M. Dammerman, E. Ravussin, C. Bogardus, D.S. Ludwig, et al. 1996. Absence of mutations in the human $\mathrm{OB}$ gene in obese/diabetic subjects. Diabetes 45:679682

119.Muzzin, P., R.C. Eisensmith, K.C Copeland, and S.L. Woo. 1996. Correction of obesity and diabetes in genetically obese mice by leptin gene therapy. Proc. Natl. Acad. Sci. USA 93:14804-14808.

120.Chen, G., K. Koyama, X. Yuan, Y. Lee, Y.T Zhou, R. O'Doherty, C.B. Newgard, and R.H. Unger. 1996. Disappearance of body fat in normal rats induced by adenovirus-mediated leptin gene therapy. Proc. Natl. Acad. Sci. USA 93:14795-14799.

121.Morsy, M.A., M.C. Gu, J.Z. Zhao, D.J. Holder, I.T. Rogers, W.J. Pouch, S.L. Motzel, H.J. Klein, et al. 1998. Leptin gene therapy and daily protein administration: a comparative study in the ob/ob mouse. Gene Ther. 5:8-18.

122.Dhillon, H., Y. Ge, R.M. Minter, V. Prima, L.L. Moldawer, N. Muzyczka, S. Zolotukhin, P.S. Kalra, and S.P. Kalra. 2000 Long-term differential modulation of genes encoding orexigenic and anorexigenic peptides by leptin delivered by rAAV vector in ob/ob mice. Relationship with body weight change. Regul. Pept. 92:97-105.

123.Murphy, J.E., S. Zhou, K. Giese, L.T. Williams, J.A. Escobedo, and V.J. Dwarki. 1997. Long-term correction of obesity and diabetes in genetically obese mice by a single intramuscular injection of recombinant adeno-associated virus encoding mouse leptin. Proc. Natl. Acad. Sci. USA 94:13921-13926.

124.Caro, J.F., J.W. Kolaczynski, M.R. Nyce, J.P. Ohannesian, I. Opentanova, W.H. Goldman, R.B. Lynn, P.L. Zhang, et al. 1996. Decreased cerebrospinal-fluid/serum leptin ratio in obesity: a possible mechanism for leptin resistance. Lancet 348:159-161.

125.Reaven, G.M. 1988. Banting lecture 1988. Role of insulin resistance in human disease. Diabetes 37:1595-1607.

126.Taylor, S.I. 1999. Deconstructing type 2 diabetes. Cell 97:9-12.

127.Olefsky, J.M. 2000. Treatment of insulin resistance with peroxisome proliferator-activated receptor gamma agonists. J. Clin. Invest. 106:467-472. 
128.Gibbs, E.M., J.L. Stock, S.C. McCoid, H.A. Stukenbrok, J.E. Pessin, R.W. Stevenson, A.J. Milici, and J.D. McNeish. 1995. Glycemic improvement in diabetic $\mathrm{db} / \mathrm{db}$ mice by overexpression of the human insulinregulatable glucose transporter (GLUT4). J. Clin. Invest. 95:1512-1518.

129.Gnudi, L., D.R. Jensen, E. Tozzo, R.H. Eckel, and B.B. Kahn. 1996. Adipose-specific overexpression of GLUT-4 in transgenic mice alters lipoprotein lipase activity. Am. J. Physiol. 270:R785-R792.

130.Gnudi, L., E. Tozzo, P.R. Shepherd, J.L. Bliss, and B.B. Kahn. 1995. High level overexpression of glucose transporter-4 driven by an adipose- specific promoter is maintained in transgenic mice on a high fat diet, but does not prevent impaired glucose tolerance. Endocrinology 136:995-1002.

131.Hansen, P.A., E.A. Gulve, B.A. Marshall, J. Gao, J.E. Pessin, J.O. Holloszy, and M. Mueckler. 1995. Skeletal muscle glucose transport and metabolism are enhanced in transgenic mice overexpressing the Glut4 glucose transporter. J. Biol. Chem. 270:16791684.

132.Tsao, T.S., A.E. Stenbit, J. Li, K.L. Houseknecht, J.R. Zierath, E.B. Katz, and M.J. Charron. 1997. Muscle-specific transgenic complementation of GLUT4-deficient mice. Effects on glucose but not lipid metabolism. J. Clin. Invest. 100:671-677.

133.Tsao, T.S., A.E. Stenbit, S.M. Factor, W. Chen, L. Rossetti, and M.J. Charron. 1999. Prevention of insulin resistance and diabetes in mice heterozygous for GLUT4 ablation by transgenic complementation of GLUT4 in skeletal muscle. Diabetes 48:775-782.

134.Kadowaki, T. 2000. Insights into insulin resistance and type 2 diabetes from knockout mouse models. J. Clin. Invest. 106:459-465.

135.Ueki, K., T. Yamauchi, H. Tamemoto, K. Tobe, R. Yamamoto-Honda, Y. Kaburagi, Y. Akanuma, Y. Yazaki, et al. 2000. Restored insulin-sensitivity in IRS-1-deficient mice treated by adenovirus-mediated gene therapy. J. Clin. Invest. 105:1437-1445.

136.Baque, S., E. Montell, J.J. Guinovart, C.B. Newgard, and A.M. Gomez-Foix. 1998 Expression of glucokinase in cultured human muscle cells confers insulin-independent and glucose concentration-dependent increases in glucose disposal and storage. Diabetes 47:1392-1398

137.Jimenez-Chillaron, J.C., C.B. Newgard, and A.M. Gomez-Foix. 1999. Increased glucose disposal induced by adenovirus-mediated transfer of glucokinase to skeletal muscle in vivo. FASEB J. 13:2153-2160.

138.Etgen, G.J., K.M. Valasek, C.L. Broderick, and A.R. Miller. 1999. In vivo adenoviral delivery of recombinant human protein kinase C-zeta stimulates glucose transport activity in rat skeletal muscle. J. Biol. Chem. 274:22139-22142.

139.Cheung, A.T., D. Ree, J.K. Kolls, J. Fuselier, D.H. Coy, and M. Bryer-Ash. 1998. An in vivo model for elucidation of the mechanism of tumor necrosis factor-alpha (TNF-alpha)-induced insulin resistance: evidence for differential regulation of insulin signaling by TNF-alpha. Endocrinology 139:4928-4935.
140.Bonner-Weir, S., M. Taneja, G.C. Weir, K. Tatarkiewicz, K.H. Song, A. Sharma, and J.J. O'Neil. 2000. In vitro cultivation of human islets from expanded ductal tissue. Proc. Natl. Acad. Sci. USA 97:7999-8004.

141.Beattie, G.M., A.D. Lopez, T. Otonkoski, and A. Hayek. 1999. Transplantation of human fetal pancreas: fresh vs. cultured fetal islets or ICCS. J. Mol. Med. 77:70-73.

142.Beattie, G.M., V. Cirulli, A.D. Lopez, and A. Hayek. 1997. Ex vivo expansion of human pancreatic endocrine cells. J. Clin. Endocrinol. Metab. 82:1852-1856.

143.Beattie, G.M., J.S. Rubin, M.I. Mally, T. Otonkoski, and A. Hayek. 1996. Regulation of proliferation and differentiation of human fetal pancreatic islet cells by extracellular matrix, hepatocyte growth factor, and cellcell contact. Diabetes 45:1223-1228.

144.Mally, M.I., T. Otonkoski, A.D. Lopez, and A. Hayek. 1994. Developmental gene expression in the human fetal pancreas. Pediatr. Res. 36:537-544.

145.Beattie, G.M., T. Otonkoski, A.D. Lopez, and A. Hayek. 1993. Maturation and function of human fetal pancreatic cells after cryopreservation. Transplantation 56:13401343

146.Gussoni, E., Y. Soneoka, C.D. Strickland, E.A. Buzney, M.K. Khan, A.F. Flint, L.M. Kunkel, and R.C. Mulligan. 1999. Dystrophin expression in the mdx mouse restored by stem cell transplantation. Nature 401:390394.

147.Julier, C., R.N. Hyer, J. Davies, F. Merlin, P. Soularue, L. Briant, G. Cathelineau, I. Deschamps, et al. 1991. Insulin-IGF2 region on chromosome $11 \mathrm{p}$ encodes a gene implicated in HLA-DR4-dependent diabetes susceptibility. Nature 354:155-159.

148.Davies, J.L., Y. Kawaguchi, S.T. Bennett, J.B. Copeman, H.J. Cordell, L.E. Pritchard, P.W. Reed, S.C. Gough, et al. 1994. A genome-wide search for human type 1 diabetes susceptibility genes. Nature 371:130-136.

149.Vafiadis, P., S.T. Bennett, J.A. Todd, J. Nadeau, R. Grabs, C.G. Goodyer, S. Wickramasinghe, E. Colle, et al. 1997. Insulin expression in human thymus is modulated by INS VNTR alleles at the IDDM2 locus. Nat. Genet. 15:289-292.

150.Cordell, H.J. and J.A. Todd. 1995. Multifactorial inheritance in type 1 diabetes. Trends Genet. 11:499-504

151.Pugliese, A., M. Zeller, A. Fernandez, Jr., L.J. Zalcberg, R.J. Bartlett, C. Ricordi, M. Pietropaolo, G.S. Eisenbarth, et al. 1997. The insulin gene is transcribed in the human thymus and transcription levels correlated with allelic variation at the INS VNTRIDDM2 susceptibility locus for type 1 diabetes. Nat. Genet. 15:293-297.

152.Wong, F.S., I. Visintin, L. Wen, R.A. Flavell, and C.A. Janeway, Jr. 1996. CD8 T cell clones from young nonobese diabetic (NOD) islets can transfer rapid onset of diabetes in NOD mice in the absence of CD4 cells. J. Exp. Med. 183:67-76.

153.Chen, W., I. Bergerot, J.F. Elliott, L.C. Harrison, N. Abiru, G.S. Eisenbarth, and T.L. Delovitch. 2001. Evidence that a pep- tide spanning the $\mathrm{B}-\mathrm{C}$ junction of proinsulin is an early Autoantigen epitope in the pathogenesis of type 1 diabetes. J. Immunol. 167:4926-4935.

154.Giorda, R., M. Peakman, K.C. Tan, D. Vergani, and M. Trucco. 1991. Glutamic acid decarboxylase expression in islets and brain. Lancet 338:1469-1470.

155.French, M.B., J. Allison, D.S. Cram, H.E. Thomas, M. Dempsey-Collier, A. Silva H.M. Georgiou, T.W. Kay, et al. 1997 Transgenic expression of mouse proinsulin II prevents diabetes in nonobese diabetic mice. Diabetes 46:34-39.

156.Posselt, A.M., A. Naji, J.H. Roark, J.F. Markmann, and C.F. Barker. 1991. Intrathymic islet transplantation in the spontaneously diabetic BB rat. Ann. Surg. 214:363373.

157.Posselt, A.M., C.F. Barker, A.L. Friedman, and A. Naji. 1992. Prevention of autoimmune diabetes in the BB rat by intrathymic islet transplantation at birth. Science 256:1321-1324.

158.Posselt, A.M., C.F. Barker, J.F. Markmann, J.H. Roark, and A. Naji. 1992. Successful islet transplantation in the thymus of spontaneously diabetic BB rats. Transplant. Proc. 24:1023-1024.

159.Koevary, S.B. and M. Blomberg. 1992. Prevention of diabetes in $\mathrm{BB} /$ Wor rats by intrathymic islet injection. J. Clin. Invest. 89:512-516.

160.Charlton, B., C. Taylor-Edwards, R. Tisch, and C.G. Fathman. 1994. Prevention of diabetes and insulitis by neonatal intrathymic islet administration in NOD mice. J. Autoimmun. 7:549-560

161.Cetkovic-Cvrlje, M., I.C. Gerling, A. Muir, M.A. Atkinson, J.F. Elliot, and E.H. Leiter. 1997. Retardation or acceleration of diabetes in NOD/Lt mice mediated by intrathymic administration of candidate beta-cell antigens. Diabetes 46:1975-1982.

162.DeMatteo, R.P., S.E. Raper, M. Ahn, K.J. Fisher, C. Burke, A. Radu, G. Widera, B.R. Claytor, et al. 1995. Gene transfer to the thymus. A means of abrogating the immune response to recombinant adenovirus. Ann. Surg. 222:229-242.

163.Ali, A., M. Garrovillo, M.X. Jin, M.A Hardy, and S.F. Oluwole. 2000. Major histocompatibility complex class I peptidepulsed host dendritic cells induce antigenspecific acquired thymic tolerance to islet cells. Transplantation 69:221-226.

164.Ali, A.O., M. Garrovillo, O.O. Oluwole, H.A. DePaz, R. Gopinathan, M.A. Hardy, and S.F. Oluwole. 2001. Induction of acquired tolerance to cardiac allografts by adoptive transfer of in vivo allopeptide activated T cells. Transplant. Proc. 33:97.

165.Oluwole, O.O., H.A. Depaz, R Gopinathan, A. Ali, M. Garrovillo, M.X. Jin, M.A. Hardy, and S.F. Oluwole. 2001 Indirect allorecognition in acquired thymic tolerance: induction of donor-specific permanent acceptance of rat islets by adoptive transfer of allopeptide-pulsed host myeloid and thymic dendritic cells. Diabetes 50:15461552 .

166.Giannoukakis, N., C.A. Bonham, S. Qian, 
Z. Chen, L. Peng, J. Harnaha, W. Li, A.W. Thomson, et al. 2000. Prolongation of cardiac allograft survival using dendritic cells treated with NF-kB decoy oligodeoxyribonucleotides. Mol. Ther. 1:430-437.

167.Thomson, A.W., L. Lu, N. Murase, A.J. Demetris, A.S. Rao, and T.E. Starzl. 1995. Microchimerism, dendritic cell progenitors and transplantation tolerance. Stem Cells 13:622-639.

168.Lenschow, D.J., Y. Zeng, J.R. Thistlethwaite, A. Montag, W. Brady, M.G. Gibson, P.S. Linsley, and J.A. Bluestone. 1992. Long-term survival of xenogeneic pancreatic islet grafts induced by CTLA4lg. Science 257:789-792.

169.Steurer, W., P.W. Nickerson, A.W. Steele, J. Steiger, X.X. Zheng, and T.B. Strom. 1995 Ex vivo coating of islet cell allografts with murine CTLA4/Fc promotes graft tolerance. J. Immunol. 155:1165-1174

170.Weber, C.J., M.K. Hagler, J.T. Chryssochoos, C.P. Larsen, T.C. Pearson, P. Jensen, J.A. Kapp, and P.S. Linsley. 1996. CTLA4-Ig prolongs survival of microencapsulated rabbit islet xenografts in spontaneously diabetic Nod mice. Transplant. Proc. 28:821-823.

171.Weber, C.J., M.K. Hagler, J.T. Chryssochoos, J.A. Kapp, G.S. Korbutt, R.V. Rajotte, and P.S. Linsley. 1997. CTLA4-Ig prolongs survival of microencapsulated neonatal porcine islet xenografts in diabetic NOD mice. Cell Transplant. 6:505-508.

172.Levisetti, M.G., P.A. Padrid, G.L. Szot, N. Mittal, S.M. Meehan, C.L. Wardrip, G.S. Gray, D.S. Bruce, et al. 1997. Immunosuppressive effects of human CTLA4Ig in a nonhuman primate model of allogeneic pancreatic islet transplantation. J. Immunol. 159:5187-5191

173.Gainer, A.L., G.S. Korbutt, R.V. Rajotte, G.L. Warnock, and J.F. Elliott. 1997. Expression of CTLA4-Ig by biolistically transfected mouse islets promotes islet allograft survival. Transplantation 63:1017-1021.

174.Chahine, A.A., M. Yu, M.M. McKernan, C. Stoeckert, and H.T. Lau. 1995. Immunomodulation of pancreatic islet allografts in mice with CTLA4Ig secreting muscle cells. Transplantation 59:1313-1318.

175. Molano, R.D., T. Berney, H. Li, P. Cattan, A. Pileggi, C. Vizzardelli, N.S. Kenyon, C. Ricordi, et al. 2001. Prolonged islet graft survival in NOD mice by blockade of the CD40-CD154 pathway of T-cell costimulation. Diabetes 50:270-276.

176.Kenyon, N.S., M. Chatzipetrou, M. Masetti, A. Ranuncoli, M. Oliveira, J.L. Wagner, A.D. Kirk, D.M. Harlan, et al. 1999. Longterm survival and function of intrahepatic islet allografts in rhesus monkeys treated with humanized anti-CD154. Proc. Natl. Acad. Sci. USA 96:8132-8137.

177.Kenyon, N.S., L.A. Fernandez, R. Lehmann, M. Masetti, A. Ranuncoli, M. Chatzipetrou, G. Iaria, D. Han, et al. 1999. Long-term survival and function of intrahepatic islet allografts in baboons treated with humanized anti-CD154. Diabetes 48:14731481

178.Seung, E., N. Iwakoshi, B.A. Woda, T.G.
Markees, J.P. Mordes, A.A. Rossini, and D.L. Greiner. 2000. Allogeneic hematopoietic chimerism in mice treated with sublethal myeloablation and anti-CD154 antibody: absence of graft-versus-host disease, induction of skin allograft tolerance, and prevention of recurrent autoimmunity in islet-allografted NOD/Lt mice. Blood 95:2175-2182.

179.Steptoe, R.J. and A.W. Thomson. 1996. Dendritic cells and tolerance induction. Clin. Exp. Immunol. 105:397-402.

180.Lu, L. and A.W. Thomson. 2002. Manipulation of dendritic cells for tolerance induction in transplantation and autoimmune disease. Transplantation 73:S19-S22.

181.Takayama, T., Y. Nishioka, L. Lu, M.T Lotze, H. Tahara, and A.W. Thomson. 1998. Retroviral delivery of viral interleukin10 into myeloid dendritic cells markedly inhibits their allostimulatory activity and promotes the induction of T-cell hyporesponsiveness. Transplantation 66:1567-1574.

182.Pugliese, A., D. Brown, D. Garza, D. Murchison, M. Zeller, M. Redondo, J. Diez, G.S. Eisenbarth, et al. 2001. Self-antigen-presenting cells expressing diabetes-associated autoantigens exist in both thymus and peripheral lymphoid organs. J. Clin. Invest. 107:555-564

183.Zhang, H.G., D. Liu, Y. Heike, P. Yang, Z. Wang, X. Wang, D.T. Curiel, T. Zhou, et al. 1998. Induction of specific T-cell tolerance by adenovirus-transfected, Fas ligandproducing antigen presenting cells. Nat Biotechnol. 16:1045-1049.

184.O'Doherty, U., R.M. Steinman, M. Peng, P.U. Cameron, S. Gezelter, I. Kopeloff, W.J. Swiggard, M. Pope, et al. 1993. Dendritic cells freshly isolated from human blood express CD4 and mature into typical immunostimulatory dendritic cells after culture in monocyte-conditioned medium. J. Exp. Med. 178:1067-1076.

185.Lu, L., A. Gambotto, W.C. Lee, S. Qian, C.A. Bonham, P.D. Robbins, and A.W. Thomson. 1999. Adenoviral delivery of CTLA4Ig into myeloid dendritic cells promotes their in vitro tolerogenicity and survival in allogeneic recipients. Gene Ther 6:554-563.

186.Piccirillo, C.A., Y. Chang, and G.J. Prud'homme. 1998. TGF-beta1 somatic gene therapy prevents autoimmune disease in nonobese diabetic mice. J. Immunol 161:3950-3956.

187.Prud'homme, G.J. and Y. Chang. 1999 Prevention of autoimmune diabetes by intramuscular gene therapy with a nonviral vector encoding an interferon-gamma receptor IgG1 fusion protein. Gene Ther. 6:771-777.

188.Prud'homme, G.J., B.R. Lawson, Y. Chang, and A.N. Theofilopoulos. 2001. Immunotherapeutic gene transfer into muscle. Trends Immunol. 22:149-155.

189.Celluzzi, C.M. and L.D. Falo, Jr. 1997. Epidermal dendritic cells induce potent antigenspecific CTL-mediated immunity. J. Invest. Dermatol. 108:716-720.

190.Condon, C., S.C. Watkins, C.M. Celluzzi, K. Thompson, and L.D. Falo, Jr. 1996. DNA-based immunization by in vivo trans- fection of dendritic cells. Nat. Med. 2:11221128 .

191.Singer, S.M., R. Tisch, X.D. Yang, H.K. Sytwu, R. Liblau, and H.O. McDevitt. 1998. Prevention of diabetes in NOD mice by a mutated I-Ab transgene. Diabetes 47:15701577.

192.Rajagopal, J., W.J. Anderson, S. Kume, O.I. Martinez, and D.A. Melton. 2003. Insulin staining of ES cell progeny from insulin uptake. Science 299:363.

193.Gainer, A.L., W.L. Suarez-Pinzon, W.P. Min, J.R. Swiston, C. Hancock-Friesen, G.S. Korbutt, R.V. Rajotte, G.L. Warnock, and J.F. Elliott. 1998. Improved survival of biolistically transfected mouse islet allografts expressing CTLA4-Ig or soluble Fas ligand. Transplantation 66:194-199.

194.Welsh, N., C. Oberg, C. Hellerstrom, and M. Welsh. 1990. Liposome mediated in vitro transfection of pancreatic islet cells. Biomed. Biochim. Acta 49:1157-1164.

195.Benhamou, P.Y., C. Moriscot, P. Prevost, E. Rolland, S. Halimi, and J. Chroboczek. 1997. Standardization of procedure for efficient ex vivo gene transfer into porcine pancreatic islets with cationic liposomes. Transplantation 63:1798-1803.

196.Smith, D.K., G.S. Korbutt, W.L. SuarezPinzon, D. Kao, R.V. Rajotte, and J.F. EIliott. 1997. Interleukin-4 or interleukin-10 expressed from adenovirus-transduced syngeneic islet grafts fails to prevent beta cell destruction in diabetic NOD mice. Transplantation 64:1040-1049.

197.Yasuda, H., M. Nagata, K. Arisawa, R. Yoshida, K. Fujihira, N. Okamoto, H. Moriyama, M. Miki, et al. 1998. Local expression of immunoregulatory IL-12p40 gene prolonged syngeneic islet graft survival in diabetic NOD mice. J. Clin. Invest. 102:18071814.

198.Benhamou, P.Y., Y. Mullen, A. Shaked, D. Bahmiller, and M.E. Csete. 1996. Decreased alloreactivity to human islets secreting recombinant viral interleukin 10 . Transplantation 62:1306-1312.

199.Judge, T.A., N.M. Desai, Z. Yang, S. Rostami, L. Alonso, H. Zhang, Y. Chen, J.F. Markman, et al. 1998. Utility of adenoviralmediated Fas ligand gene transfer to modulate islet allograft survival. Transplantation 66:426-434.

200.von Herrath, M.G., S. Efrat, M.B. Oldstone, and M.S. Horwitz. 1997. Expression of adenoviral E3 transgenes in beta cells prevents autoimmune diabetes. Proc. Natl. Acad. Sci. USA 94:9808-9813.

201.Weber, M., S. Deng, T. Kucher, A. Shaked, R.J. Ketchum, and K.L. Brayman. 1997 Adenoviral transfection of isolated pancreatic islets: a study of programmed cell death (apoptosis) and islet function. J. Surg. Res. 69:23-32.

202.Csete, M.E., P.Y. Benhamou, K.E. Drazan, L. Wu, D.F. McIntee, R. Afra, Y. Mullen, R.W. Busuttil, et al. 1995. Efficient gene transfer to pancreatic islets mediated by adenoviral vectors. Transplantation 59:263-268.

203.Raper, S.E. and R.P. DeMatteo. 1996. Adenovirus-mediated in vivo gene transfer and expression in normal rat pancreas. Pancreas 
12:401-410.

204.Saldeen, J., D.T. Curiel, D.L. Eizirik, A. Andersson, E. Strandell, K. Buschard, and N. Welsh. 1996. Efficient gene transfer to dispersed human pancreatic islet cells in vitro using adenovirus-polylysine/DNA complexes or polycationic liposomes. Diabetes 45:1197-1203.

205.Grey, S.T., M.B. Arvelo, W. Hasenkamp, F.H. Bach, and C. Ferran. 1999. A20 inhibits cytokine-induced apoptosis and nuclear factor kappaB-dependent gene activation in islets. J. Exp. Med. 190:1135-1146.

206.Muruve, D.A., R.C. Manfro, T.B. Strom and T.A. Libermann. 1997. Ex vivo adenovirus-mediated gene delivery leads to longterm expression in pancreatic islet transplants. Transplantation 64:542-546.

207.Becker, T.C., H. BeltrandelRio, R.J. Noel, J.H. Johnson, and C.B. Newgard. 1994 Overexpression of hexokinase I in isolated islets of Langerhans via recombinant adenovirus. Enhancement of glucose metabolism and insulin secretion at basal but not stimulatory glucose levels. J. Biol. Chem. 269:21234-21238.

208.Giannoukakis, N., W. A. Rudert, S. C. Ghivizzani, A. Gambotto, C. Ricordi, M. Trucco, and P. D. Robbins. 1999. Adenoviral gene transfer of the interleukin-1 receptor antagonist protein to human islets prevents IL-1beta-induced beta-cell impairment and activation of islet cell apoptosis in vitro. Diabetes 48:1730-1736.

209.Giannoukakis, N., W.A. Rudert, M. Trucco, and P.D. Robbins. 2000. Protection of human islets from the effects of interleukin1 beta by adenoviral gene transfer of an IkappaB repressor. J. Biol. Chem. 275:3650936513

210.Flotte, T., A. Agarwal, J. Wang, S. Song, E.S. Fenjves, L. Inverardi, K. Chesnut, S. Afione, et al. 2001. Efficient ex vivo transduction of pancreatic islet cells with recombinant adeno-associated virus vectors. Diabetes 50:515-520.

211.Yang, Y.W. and R.M. Kotin. 2000. Glucoseresponsive gene delivery in pancreatic Islet cells via recombinant adeno-associated viral vectors. Pharm. Res. 17:1056-1061.

212.Kapturczak, M., S. Zolotukhin, J. Cross, A. Pileggi, R.D. Molano, M. Jorgensen, B. Byrne, T.R. Flotte, et al. 2002. Transduction of human and mouse pancreatic islet cells using a bicistronic recombinant adeno-associated viral vector. Mol. Ther. 5:154-160.

213.Shifrin, A.L., A. Auricchio, Q.C. Yu, J. Wilson, and S.E. Raper. 2001. Adenoviral vector-mediated insulin gene transfer in the mouse pancreas corrects streptozotocin-induced hyperglycemia. Gene Ther. 8:14801489.

214.Contreras, J.L., G. Bilbao, C. Smyth, D.E. Eckhoff, X.L. Xiang, S. Jenkins, S. Cartner, D.T. Curiel, et al. 2001. Gene transfer of the Bcl-2 gene confers cytoprotection to isolated adult porcine pancreatic islets exposed to xenoreactive antibodies and complement. Surgery 130:166-174

215.Alexander, A.M., M. Crawford, S. Bertera, W.A. Rudert, O. Takikawa, P.D. Robbins, and M. Trucco. 2002. Indoleamine 2,3- dioxygenase expression in transplanted NOD Islets prolongs graft survival after adoptive transfer of diabetogenic splenocytes. Diabetes 51:356-365.

216.Contreras, J.L., G. Bilbao, C.A. Smyth, X.L. Jiang, D.E. Eckhoff, S.M. Jenkins, F.T. Thomas, D.T. Curiel, et al. 2001. Cytoprotection of pancreatic islets before and soon after transplantation by gene transfer of the anti-apoptotic Bcl-2 gene. Transplantation 71:1015-1023.

217.Uchikoshi, F., Z.D. Yang, S. Rostami, Y. Yokoi, P. Capocci, C.F. Barker, and A. Naji. 1999. Prevention of autoimmune recurrence and rejection by adenovirus-mediated CTLA4Ig gene transfer to the pancreatic graft in BB rat. Diabetes 48:652-657.

218.Moriscot, C., F. Pattou, J. Kerr-Conte, M.J. Richard, P. Lemarchand, and P.Y. Benhamou. 2000. Contribution of adenoviral-mediated superoxide dismutase gene transfer to the reduction in nitric oxide-induced cytotoxicity on human islets and INS-1 insulin-secreting cells. Diabetologia 43:625631.

219.Guo, Z., J. Shen, D. Mital, Y. Hong, R. Alemany, W.W. Zhong, S.C. Jensik, and J.W. Williams. 1999. Efficient gene transfer and expression in islets by an adenoviral vector that lacks all viral genes. Cell Transplant. 8:661-671.

220.Leibowitz, G., G.M. Beattie, T. Kafri, V. Cirulli, A.D. Lopez, A. Hayek, and F. Levine. 1999. Gene transfer to human pancreatic endocrine cells using viral vectors. Diabetes 48:745-753.

221.Gallichan, W.S., T. Kafri, T. Krahl, I.M. Verma, and N. Sarvetnick. 1998. Lentivirus-mediated transduction of islet grafts with interleukin 4 results in sustained gene expression and protection from insulitis. Hum. Gene Ther. 9:2717-2726.

222.Ju, Q., D. Edelstein, M.D. Brendel, D. Brandhorst, H. Brandhorst, R.G. Bretzel, and M. Brownlee. 1998. Transduction of non-dividing adult human pancreatic beta cells by an integrating lentiviral vector. Diabetologia 41:736-739.

223.Giannoukakis, N., Z. Mi, A. Gambotto, A. Eramo, C. Ricordi, M. Trucco, and P. Robbins. 1999. Infection of intact human islets by a lentiviral vector. Gene Ther. 6:15451551

224.Liu, Y., A. Rabinovitch, W. Suarez-Pinzon, B. Muhkerjee, M. Brownlee, D. Edelstein, and H.J. Federoff. 1996. Expression of the bcl-2 gene from a defective HSV-1 amplicon vector protects pancreatic beta-cells from apoptosis. Hum. Gene Ther. 7:1719-726.

225.Rabinovitch, A., W. Suarez-Pinzon, K. Strynadka, Q. Ju, D. Edelstein, M. Brownlee, G.S. Korbutt, and R.V. Rajotte. 1999. Transfection of human pancreatic islets with an anti-apoptotic gene (bcl-2) protects betacells from cytokine-induced destruction. Diabetes 48:1223-1229.

226.Dupraz, P., C. Rinsch, W.F. Pralong, E. Rolland, R. Zufferey, D. Trono, and B. Thorens. 1999. Lentivirus-mediated Bcl-2 expression in betaTC-tet cells improves resistance to hypoxia and cytokine-induced apoptosis while preserving in vitro and in vivo control of insulin secretion. Gene Ther 6:1160-1169

227.Zhou, Y.P., J.C. Pena, M.W. Roe, A. Mittal, M. Levisetti, A.C. Baldwin, W. Pugh, D. Ostrega, et al. 2000. Overexpression of Bcl$\mathrm{x}(\mathrm{L})$ in beta-cells prevents cell death but impairs mitochondrial signal for insulin secretion. Am. J. Physiol. Endocrinol. Metab. 278:E340-E351.

228.Tobiasch, E., L. Gunther, and F.H. Bach. 2001. Heme oxygenase- 1 protects pancreatic beta cells from apoptosis caused by various stimuli. J. Investig. Med. 49:566-571.

229.Pileggi, A., R.D. Molano, T. Berney, P. Cattan, C. Vizzardelli, R. Oliver, C. Fraker, C. Ricordi, et al. 2001. Heme oxygenase-1 in duction in islet cells results in protection from apoptosis and improved in vivo function after transplantation. Diabetes 50:1983-1991.

230.Ye, J. and S.G. Laychock. 1998. A protective role for heme oxygenase expression in pancreatic islets exposed to interleukin-1beta. Endocrinology 139:4155-4163.

231.Carpenter, L., D. Cordery, and T.J. Biden. 2002. Inhibition of protein kinase $\mathrm{C}$ delta protects rat INS-1 cells against interleukin1 beta and streptozotocin-induced apoptosis Diabetes 51:317-324.

232.Dupraz, P., S. Cottet, F. Hamburger, W Dolci, E. Felley-Bosco, and B. Thorens. 2000. Dominant negative MyD88 proteins inhibit interleukin-1 beta /interferon-gammamediated induction of nuclear factor kappa B-dependent nitrite production and apoptosis in beta cells. J. Biol. Chem. 275:37672 37678 .

233.Giannoukakis, N., Z. Mi, W.A. Rudert, A Gambotto, M. Trucco, and P. Robbins. 2000. Prevention of beta cell dysfunction and apoptosis activation in human islets by adenoviral gene transfer of the insulin-like growth factor I. Gene Ther. 7:2015-2022.

234.Burkart, V., H. Liu, K. Bellmann, D. Wissing, M. Jaattela, M.G. Cavallo, P. Pozzilli, K. Briviba, et al. 2000. Natural resistance of human beta cells toward nitric oxide is mediated by heat shock protein 70. J. Biol. Chem. 275:19521-19528.

235.Xu, B., J.T. Moritz, and P.N. Epstein. 1999 Overexpression of catalase provides partia protection to transgenic mouse beta cells. Free Radic. Biol. Med. 27:830-837.

236.Benhamou, P.Y., C. Moriscot, M.J. Richard, O. Beatrix, L. Badet, F. Pattou, J. Kerr-Conte, J. Chroboczek, et al. 1998. Adenovirus-mediated catalase gene transfer reduces oxidant stress in human, porcine and rat pancreatic islets. Diabetologia 41:10931100

237.Hohmeier, H.E., A. Thigpen, V.V. Tran, R. Davis, and C.B. Newgard. 1998. Stable expression of manganese superoxide dismutase (MnSOD) in insulinoma cells prevents IL1beta-induced cytotoxicity and reduces nitric oxide production. J. Clin. Invest. 101:18111820.

238.Bertera, S., M.L. Crawford, A.M. Alexander, G.D. Papworth, S.C. Watkins, P.D. Robbins, and M. Trucco. 2003. Gene transfer of manganese superoxide dismutase extends islet graft function in a mouse model of autoimmune diabetes. Diabetes 52:387-393. 
239.Yang, Z., M. Chen, R. Wu, L.B. Fialkow, J.S. Bromberg, M. McDuffie, A. Naji, and J.L. Nadler. 2002. Suppression of autoimmune diabetes by viral IL-10 gene transfer. J. Immunol. 168:6479-6485.

240.Deng, S., R.J. Ketchum, Z.D. Yang, T. Kucher, M. Weber, A. Shaked, A. Naji, and K.L. Brayman. 1997. IL-10 and TGF-beta gene transfer to rodent islets: effect on xenogeneic islet graft survival in naive and B-celldeficient mice. Transplant. Proc. 29:22072208.

241.Hao, W. and J.P. Palmer. 1995. Recombinant human transforming growth factor beta does not inhibit the effects of interleukin-1 beta on pancreatic islet cells. J. Interferon. Cytokine Res. 15:1075-1081.

242.Kang, S.M., D.B. Schneider, Z. Lin, D. Hanahan, D.A. Dichek, P.G. Stock, and S. Baekkeskov. 1997. Fas ligand expression in islets of Langerhans does not confer immune privilege and instead targets them for rapid destruction. Nat. Med. 3:738-743.

243.Leykin, I., B. Nikolic, and M. Sykes. 2001. Mixed bone marrow chimerism as a treatment for autoimmune diabetes. Transplant. Proc. 33:120.

244.Mathieu, C., R. Bouillon, O. Rutgeerts, and M. Waer. 1995. Induction of mixed bone marrow chimerism as potential therapy for autoimmune (type I) diabetes: experience in the NOD model. Transplant. Proc. 27:640641

245.Mathieu, C., K. Casteels, R. Bouillon, and M. Waer. 1997. Protection against autoimmune diabetes in mixed bone marrow chimeras: mechanisms involved. J. Immunol. 158:1453-1457.

246.Girman, P., J. Kriz, E. Dovolilova, E. Cihalova, and F. Saudek. 2001. The effect of bone marrow transplantation on survival of allogeneic pancreatic islets with short-term tacrolimus conditioning in rats. Ann. Transplant. 6:43-45.

247.Li, H., Y.L. Colson, and S.T. Ildstad. 1995. Mixed allogeneic chimerism achieved by lethal and nonlethal conditioning approaches induces donor-specific tolerance to simultaneous islet allografts. Transplantation 60:523-529.

248.Li, H., C.L. Kaufman, and S.T. Ildstad. 1995. Allogeneic chimerism induces donorspecific tolerance to simultaneous islet allografts in nonobese diabetic mice. Surgery 118:192-198.

249.Li, H., C. Ricordi, A.J. Demetris, C.L. Kaufman, C. Korbanic, M.L. Hronakes, and S.T. Ildstad. 1994. Mixed xenogeneic chimerism (mouse+rat $\rightarrow$ mouse) to induce donor-specific tolerance to sequential or simultaneous islet xenografts. Transplantation 57:592-598.

250.Britt, L.D., D.W. Scharp, P.E. Lacy, and S. Slavin. 1982. Transplantation of islet cells across major histocompatibility barriers after total lymphoid irradiation and infusion of allogeneic bone marrow cells. Diabetes 31 (Suppl 4):63-68.

251.Rossini, A.A., J.P. Mordes, D.L. Greiner, and J.S. Stoff. 2001. Islet cell transplantation tolerance. Transplantation 72:S43-S46.

252.Li, H., L. Inverardi, and C. Ricordi. 1999.
Chimerism-induced remission of overt diabetes in nonobese diabetic mice. Transplant. Proc. 31:640.

253.Mathieu, C., M. Vandeputte, R. Bouillon, and M. Waer. 1993. Protection against autoimmune diabetes by induction of mixed bone marrow chimerism. Transplant. Proc. 25:1266-1267.

254.Feili-Hariri, M., X. Dong, S.M. Alber, S.C. Watkins, R.D. Salter, and P.A. Morel. 1999. Immunotherapy of NOD mice with bone marrow-derived dendritic cells. Diabetes 48:2300-2308.

255.Bertry-Coussot, L., B. Lucas, C. Danel, L. Halbwachs-Mecarelli, J.F. Bach, L. Chatenoud, and P. Lemarchand. 2002. Longterm reversal of established autoimmunity upon transient blockade of the LFA-1/intercellular adhesion molecule-1 pathway. J. Immunol. 168:3641-3648.

256.Georgiou, H.M., J.L. Brady, A. Silva, and A.M. Lew. 1997. Genetic modification of an islet tumor cell line inhibits its rejection. Transplant. Proc. 29:1032-1033.

257.Lew, A.M., J.L. Brady, A. Silva, J.E. Coligan, and H.M. Georgiou. 1996. Secretion of CTLA4Ig by an SV40 T antigen-transformed islet cell line inhibits graft rejection agains the neoantigen. Transplantation 62:83-89.

258.Weber, C.J., M.K. Hagler, J.T. Chryssochoos, C.P. Larsen, T.C. Pearson, P. Jensen, J.A. Kapp, and P.S. Linsley. 1996 CTLA4-Ig prolongs survival of microencapsulated rabbit islet xenografts in spontaneous ly diabetic Nod mice. Transplant. Proc. 28:821-823

259.Brady, J.L. and A.M. Lew. 2000. Additive efficacy of CTLA4Ig and OX40Ig secreted by genetically modified grafts. Transplantation 69:724-730

260.Sutherland, R.M., J.L. Brady, H.M. Georgiou, H.E. Thomas, and A.M. Lew. 2000 Protective effect of CTLA4Ig secreted by transgenic fetal pancreas allografts. Transplantation 69:1806-1812

261.Goudy, K., S. Song, C. Wasserfall, Y.C. Zhang, M. Kapturczak, A. Muir, M. Powers, M. Scott-Jorgensen, et al. 2001. Adenoassociated virus vector-mediated IL-10 gene delivery prevents type 1 diabetes in NOD mice. Proc. Natl. Acad. Sci. USA 98:13913 13918.

262.Ko, K.S., M. Lee, J.J. Koh, and S.W. Kim. 2001. Combined administration of plasmid encoding IL-4 and IL-10 prevents the development of autoimmune diabetes in nonobese diabetic mice. Mol. Ther. 4:313-316

263.Koh, J.J., K.S. Ko, M. Lee, S. Han, J.S Park, and S.W. Kim. 2000. Degradable polymeric carrier for the delivery of IL-10 plasmid DNA to prevent autoimmune insulitis of NOD mice. Gene Ther. 7:2099-2104

264.Zipris, D. and E. Karnieli. 2002. A single treatment with IL-4 via retrovirally transduced lymphocytes partially protects agains diabetes in BioBreeding (BB) rats. JOP 3:7682

265.Chang, Y. and G.J. Prud'homme. 1999. Intramuscular administration of expression plasmids encoding interferon- gamma receptor/IgG1 or IL-4/IgG1 chimeric proteins protects from autoimmunity. J. Gene Med.
$1: 415-423$

266.Piccirillo, C.A., Y. Chang, and G.J. Prud'homme. 1998. TGF-beta1 somatic gene therapy prevents autoimmune disease in nonobese diabetic mice. J. Immunol. 161:3950-3956.

267.Balasa, B., B.O. Boehm, A. Fortnagel, W. Karges, K. Van Gunst, N. Jung, S.A. Camacho, S.R. Webb, et al. 2001. Vaccination with glutamic acid decarboxylase plasmid DNA protects mice from spontaneous autoimmune diabetes and B7/CD28 costimulation circumvents that protection. Clin. Immunol. 99:241-252

268.Efrat, S., D. Serreze, A. Svetlanov, C.M. Post, E.A. Johnson, K. Herold, and $M$. Horwitz. 2001. Adenovirus early region 3(E3) immunomodulatory genes decrease the incidence of autoimmune diabetes in NOD mice. Diabetes 50:980-984.

269.Weiner, H.L., A. Friedman, A. Miller, S.J. Khoury, A. al-Sabbagh, L. Santos, M Sayegh, R.B. Nussenblatt, et al. 1994. Oral tolerance: immunologic mechanisms and treatment of animal and human organ-specific autoimmune diseases by oral administration of autoantigens. Annu. Rev. Immunol. 12:809-837.

270.Polanski, M., N.S. Melican, J. Zhang, and H.L. Weiner. 1997. Oral administration of the immunodominant B-chain of insulin reduces diabetes in a co-transfer model of diabetes in the NOD mouse and is associated with a switch from Th1 to Th2 cytokines. J. Autoimmun. 10:339-346.

271.Bergerot, I., G.A. Arreaza, M.J. Cameron, M.D. Burdick, R.M. Strieter, S.W. Chensue, S. Chakrabarti, and T.L. Delovitch. 1999. Insulin B-chain reactive CD4+ regulatory T-cells induced by oral insulin treatment protect from type 1 diabetes by blocking the cytokine secretion and pancreatic infiltration of diabetogenic effector T-cells. Diabetes 48:1720-1729.

272.Prud'homme, G.J., Y. Chang, and X. Li. 2002. Immunoinhibitory DNA vaccine protects against autoimmune diabetes through cDNA encoding a selective CTLA-4 (CD152) ligand. Hum. Gene Ther. 13:395406.

273.Glorioso, J.C., W.F. Goins, M.C. Schmidt, T. Oligino, D.M. Krisky, P.C. Marconi, J.D. Cavalcoli, R. Ramakrishnan, et al. 1997. Engineering herpes simplex virus vectors for human gene therapy. Adv. Pharmacol. 40:103-136.

\section{Address correspondence to:}

Massimo Trucco

Division of Immunogenetics

Department of Pediatrics

University of Pittsburgh School of Medicine

Rangos Research Center

3460 Fifth Avenue

Pittsburgh, PA 15213, USA

e-mail:mnt@pitt.edu 